\title{
POLÍTICA: (RE)COMPOSIÇÃO DO OBJETO
}

\author{
Luiz Sergio Modesto \\ Professor Especialista em Direito Político, Administrativo e \\ Financeiro, Mestre e Doutor em Teoria do Estado pela \\ Universidade de São Paulo, pós-doutorado com título de Doutor \\ em Comunicação e Semiótica pela Pontifícia Universidade \\ Católica de São Paulo.
}

Resumo

Política: (re)composição do objeto. O autor pretende demonstrar que a "força" é um dado superestimado da política, por pelição de princípio dos modelos teóricos que instrumentalizam a Sociologia, a Teoria Política, e a normação da espécie Direito (Normação latina e anglo-saxã), e em razão de tais disciplinas compartilharem do cadinho mitologico ácade, reproduzido por helenos e hebreus, e induzido na diluição religiosa dos respectivos fundamentos cognitivos.

Sobre o objeto política (mando e força justificáveis), o autor superporá o método complexo físico-semiótico (1) da Semioselogia, includente da fenomenologia Física (Heisenberg, Bohr, Lao Tzy), da Signologia (Peirce), do Instrumento Operacional da Progmática (Modesto), e (2) da Hominilogia (Modesto), para descrever comparativamente os padrões de civilidade na família hominidæ (bonobos, humanos, chimpanzés), e quais deles dominam na ação política por mando (Normações) e por força dos humanos no mercado mundial, respectivamente, política bonobo e política chimpanzé.

\begin{abstract}
Politics: (re)composition of the object. The author intends to demonstrate that the "force" is a superestimated datum of the politics, for postulation of the beginning of the theoretical models that instrumentalize the Sociology, the Political Theory, and the normaction of the species Law (latin and anglo-saxon Normaction), and in reason of such disciplines in partaking as cognitive foundation the mythological acadian crucible, reproduced by greeks and hebrews, and induced in the religious dilution of the respective cognitive foundations.

On the politics object (justifiable exact and force), the author will superpose the semiotics-physics complex method (1) of the Semioselogy, including of the Physics phenomenology (Heisenberg, Bohr, Lao Tzy), of the Signology (Peirce), of the Progmatic Operational Instrument (Modesto), and (2) of the Hominilogy (Modesto), to comparatively describe the civility patterns in the hominidæ family (bonobos, humans, chimpanzees), and which dominate in the political action by exact (Normactions) and by force of the humans in the world market, respectively, bonobo politics and chimpanzee politics.
\end{abstract}


Unitermos: Política; Normação; normóide; Semioselogia; progmática; Hominilogia; superposição política; família hominida; política chimpanzé; incivilidade; política humana; pré-civilidade; política bonobo; civilidade

Índice

1. Forf̧a: dado superestimado da Política

2. Sociologia, Teoria Política, Direito (Normação): Mitologia por fundamento cognitivo

3. Entre bonobos e chimpanzés: humanos?

4. Formas de "Direito" (Normação): berro ou homicídio e matança?

5. Teorias de Estado: opção chimpanzé

6. Política bonobo e política chimpanzé: intermitências

\section{Força: dado superestimado da Política}

Ao colocarmos em sintaxe os modelos teóricos cujo objeto implica a política - mando ou força justificáveis -, quer pertençam à Sociologia, quer à Teoria Política, quer à normação da espécie Direito, notaremos nessa sintaxe um núcleo comum de asserções apresentando menos uma descrição de freqüência e mais uma justificação da "força" nas relações entre os humanos, expondo a ausência de distância crítica necessária e própria ao conhecimento científico sensu stricto, aquele que instrumentaliza hipóteses intersubjetivamente verificadas e demonstradas com sentido de universalidade em relação objetiva com a realidade, não circunscritas ao código verbal, pela persuasão e pela "asserção de autoridade" Essa ausência de distância crítica revela que tais disciplinas não se destacam do baixo repertório do conhecimento comum para o alto repertório do conhecimento científico. (Modesto, 1999; 1997-a)

O mando, como constituinte da política, pode ser observado na dinâmica entre coletividades do planeta pela normação (9 classe sígnica: símbolo dicente envolvente da $7^{\text {t }}$ classe sígnica e replicante da $4^{\text {il }}$ classe sígnica, esta um singular da exemplaridade, $5^{\sharp}$ classe sígnica Modesto, 1999; Peirce, 1978-2.262, 2.260, 2.257, 2.258: 149, 148, J47).

O gênero normação implica repertório mundial de exemplos e ações assimétricas na relação mando/acato movidos por multívocos interesses mediante conduta e mando de dogma. A normação pode ser observada na diversidade ambiental, doméstica ou pública, diacrônica ou sincrônica, de múltiplas ações normativas entre dominantes e dominados por exemplaridade (como o wu wei ou vago fazer da etnia han e freqüente na Coletividade-Família), por mando-casual ou singular, ou mandocausal ou formal. Nesse caso o Direito, subsumido à normação, implica a espécie histórica anglo-saxã (mando-casual ou precedente hierático) e a espécie latina (mandocausal ou "lei coletiva") de mando. 
No tocante ao constituinte político "força", buscando indiciar o problema da sua justificação trazido pela constatação acima, quanto às três disciplinas apontadas, alinharemos diacronicamente suas expressões criptodogmáticas. O signo "força", fenomenologicamente tomado, e dando consequiência ao seu sentido técnico unívoco sem implicar eufemismo, denota relação diádica de mobilização da energia física do corpo emissor no subjugo do corpo receptor. Qualquer que seja a motivação, ou a conseqüência lesiva, graduada entre o ultraje (resíduo de força), a contusão, a mutilação, e o homicídio, na relação de força (esforço/resistência) não há razão, por dominância do acaso.

Observada a delimitação terminológica, começamos pelo assumido berço grego de parcela ocidental da humanidade, com a Teoria Polílica de Aristóteles (-384 a -322). Para ele, "[m]esmo um governante supremo respeitador cla lei que, de sua livie

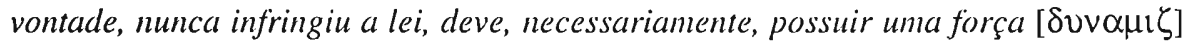
para fazer respeitur as leis" (1998-1286b: 255).

O Direito, cuja Teoria Jurídica tem por objeto a Dogmática Jurídica, fundado nessa sintaxe entre "força" e "lei". pontua a relação mais complexa entre "força" "originária" e coletividade "dominante" (ou Estado) na Teoria do Estado. Para Georg Jellinek (1851 a 1911), as relações que se estabelecem num determinado território são relações entre um poder dominante (Herrschersgewalt) de associação e um poder não dominante de associação, caracterizando-se este pela carência "de força [Gewalt] bastante para obrigar com seus próprios meios a execução de suas ordens"

Assim, o que distinguiria a "força" da Coletividade-"Estado" da "força" das demais coletividades no território seria a qualidade dominante (Herrschen - mandar) da coletividade associada, dotando-a do "direito de dominação (...) en virtude da força que lhe é originária (...). O poder que está dotado desta força é um poder de dominação, $e$, por conseguinte, poder do Estado" (Jellinek, 1954: 320, 322).

Alinhado ao mesmo sentido acrítico, encontramos na Sociologia de Max Weber (1864-1920) a asserção de que o "monopólio exitoso" da "força" é o meio específico da Coletividade-"Estado". Partindo de Trotski (Lev Davidovitch Bronstein, 1879-1940), assevera o autor que "[t]odo Estado se baseia na força [Gewalt]". pelo que, "sociologicamente o Estado moderno em última instância somente pode definirse a partir de um meio especifico que, semelhante a toda associação política, lhe é próprio, a saber: o da coação física. (...) [O] Estado é aquela comunidade humana que no interior de um determinado território (...) reclama para si (com êxito) o monopólio da coação física legítima" (1980: 1056).

Com os dados políticos da "força" e do mando, as três disciplinas apontadas fundam-se no paralogismo, ou petição de princípio, que se apóia seletiva e persuasivamente apenas na "força" como dado superestimado da política, a "força" como o redutor político das coletividades de um território à pecking order da Coletividade-Estado, partindo da tese não demonstıada de que essa "força" seria necessária numa relação de dominação entre coletividades.

Para re-compor o objeto da política com suas variáveis complementares do mando $e$ (não só) da força, passíveis de justificação, com suas freqüências e oscilos 
de dominância, o autor superporá (fig. 1) o método complexo físico-semiótico (1) da Semioselogia, includente da fenomenologia Física (Heisenberg, 1989: 42-43, Bohr, 1995: 47-76; Lao Tzy, inédito), da Signologia (Peirce, 1978-1.347: 177; 1978-2.254/ 263: 146-149), do Instrumento Operacional da Progmática (Modesto, 1994, 1999), e (2) da Hominilogia (Modesto, 1999).

\begin{tabular}{|c|c|c|c|c|}
\hline \multicolumn{5}{|c|}{ CORRELAÇŌES FENOMENOLÓGICAS (SEMIOSELOGIA) } \\
\hline LAOTZY & $B O H R$ & IEISENBERG & MODESTO & \\
\hline $\begin{array}{l}\text { primeiridade } \downarrow_{\text {acaso }} \text { flexão yin-yang } \\
\text { secundidade } \downarrow_{\text {relação matéria }} \\
\text { terceiridade } \downarrow_{\text {signo }} \text { conhecimento }\end{array}$ & $\begin{array}{l}\text { incerteza onda-corpo } \\
\text { sujeito / ubjeto } \\
\text { formalismo }\end{array}$ & $\begin{array}{l}\text { possivel eutinia } \\
\text { real mercado } \\
\text { registro convenção }\end{array}$ & $\begin{array}{l}\text { politica: mando } \\
\text { politica: mando } V \text { força } \\
\text { politica: mando }\end{array}$ & $\begin{array}{l}\text { Col. Família } \\
\text { Col. Bando } \\
\text { Col. Estado }\end{array}$ \\
\hline
\end{tabular}

Figura / Correlaçòes Fenomenológicas ou seta do lempo: Peirce, Lao Tzy, Bohr, Heisenberg, Modesto

Por meio da Semioselogia, o que se observa na história diacrônica ou sincrônica, é que a ação política se vale freqüentemente da normação (I) do exemplo (式-shih), e dominantemente (II) do mando, nas suas várias formas, do mando casual, com modelos (法 - fa) e ritos. (禮 - $l i$ ), como nas culturas orientais de tipo étnico han (chineses), e com a lex in casu, como nas culturas ocidentais de tipo étnico anglosaxão, (III) ao mando causal, mediante normações variadas, com a lex in genere, como nas culturas de tipo étnico latino (ver Modesto, 1997-a).

Esta asserção da dominância (alta freqüência) da política por mando é demonstrada (ver dados nos itens 4 e 6 ) pelo registro histórico diacrônico da normação que interfacia a relação dominante/dominado entre coletividades diversas do mercado mundial, como feito por Gilissen (1995) e David (1996), com reparo apenas à designação "direito" qual gênero, como feita por tais autores.

Cada Coletividade-Estado historicamente constrói o seu conceito de "Estado" ou equivalente sígnico de superposição política, por mando que supõe convencionalidade acatada pelas demais coletividades de determinado ambiente territorial dominado, assim expressando intermitência de interesses relativos no mercado territorial ou no mercado extraterritorial. Por consequiência o signo "Direito" quando referido e não-subsumido a essa diversidade da Normação, implica, não-só o erro lógico de designar o gênero Normação (cotejar Peters, 1983: 159) por uma de suas espécies histórica e geograficamente circunstanciada, caso da normação de espécie latina designada direito, como também eurocentrismo.

Tomando por modelo o formalismo de Bohr para descrever a ação normativa, normação implica a ação de um sujeito vinculando seu legisigno (ou signo de lei) a uma conduta subjugada, seu objeto de qualidade incerta (sua "onda"), produzindo no mercado mundial multiformes espécies dogmáticas: (I) signos de conduta, (II) signos de lei singular, ou (III) signos de lei coletiva.

A ação mediante força pode ser observada diacronicamente nos registros históricos e sincronicamente pelos jornais diários no mercado mundial como um meio 
disseminado e freqüente de superposição política entre indivíduos ou coletividades da espécie Homo sapiens, pouco diferenciada nesse quesito de outras espécies animais.

A espécie humana, para simular uma diferença inexistente com o reino animal no uso da força, contudo, dissimula sua realidade mediante justificativas nominais para induzir recepção acrítica, casos da força redesignada "defesa preventiva ou defesa iminente", da força redesignada "legítima", do homicídio redesignado "pena" da guerra redesignada "justa" O que tais redesignações desprezam é a contingência fenomenológica de qualidade da força que permanece indiciada na lesão, e não na convenção que a redesigna como "defesa" "legítima" "pena" signos estes falseados pela realidade, por verificação empírica.

Em relação a seus objetos-força, os signos "defesa", "legítimo”, "pena”, "justo" são símbolos dicentes, i. e., verdadeiros ou falsos, são problemáticos porque dominantemente dependentes de argumentação, enquanto a força é um sinsigno dicente só dependente de índices, portanto só residualmente problemática. Suprimir a força, portanto, implica menor custo do que justificá-la.

A nominal recepção ou atribuição de circunstancial conduta a um humano em coletividade, bem como as expectativas que ela reproduz, não dissolvem as diferenças fenomenológicas qualitativas e quantitativas de realidade da força. Uma nominal Coletividade-Estado, com sua liberdade convencionada, e uma nominal ColetividadeFamília, com sua liberdade acausal, ambas no uso da liberdade conflitiva mediante força, decaem dos nomes coletivos Estado e Família para corresponder à liberdade fenomenológica real da Coletividade-Bando, a despeito das designações nominais "Família" e "Estado" de suas superposições políticas, que nestes casos implicam designações empiricamente falseadas pela realidade da força, própria da pré-civilidade (item 3, fig. 2).

A superposição pode ser descrita enquanto liberdade acausal no espaçotempo intercorporal implicando intermitência política, por mando ou por força justificáveis, entre Coletividades. A superposição implica imposição efetiva de uma vontade singular, a despeito de resistências.

A (c) Coletividade (ou o Coletivo) está no conjunto fenomenológico aleatório, intermitente, e não reificável de $E$ missores $(E c)$ ou Receptores $(R c)$ diversifïcados (no campo do domínio, em relação ao campo da imagem), que tem por eixo de referência qualquer liberdade corporal ou intercorporal, quer implique a mente (liberdade da mente enquanto quale emocional), quer denote ou designe a vontade (liberdade da vontade enquanto energia), ou exprima a norma (liberdade da norma enquanto lógica). O mínimo Coletivo pode ser observado empiricamente no tribalismo humano de qualquer Coletividade-Família no seu espaço doméstico. (comparar com Ridley, 2000: 171-219)

A intermitência da superposição de uma de tais coletividades, se altamente freqüente, pode casualmente designar como dominante o Emissor coletivo em relação às coletividades Receptoras dominadas. Nesse caso, a referência à relação dominante/ dominado não implica linearidade entre coletividades, mas complexidade frequiêncial de intermitências. 
Por critério de dominância macrofenomenológica relativamente à infinidade de coletividades possíveis no real, o Ego hominida pode observar três Coletividades disponiveis para sintaxes diádicas de superposição política nos espaçostempos intercorporais doméstico e público: a Coletividade-Familia, a ColetividadeBando, a Coletividade-Estado. A superposição política ocorre por mando ou por força, com procedivel ação sígnica justificativa. A aplicação do método físico-semiótico da fenomenologia a tais Coletividades, portanto, implica irredutibilidade de suas verificações de gênero às asserções de espécie da Teoria Jurídica e da Dogmática Jurídica quanto aos signos Família, Bando, Estado.

Observa-se a Coletividade-Familia na intermitente superposição política, cuja liberdade no espaço-tempo intercorporal tem por doninância o acaso perpassado pela contigüidade corpo-corpo nas relações eutínicas, e pelas relações propriamente políticas de mando na temporalidade local do espaço doméstico.

Observa-se a Coletividade-Bando na intermitente superposição política, cuja liberdade no espaço-tempo intercorporal tem por dominância o contraste (por mando) ou o conflito (por força) com a Coletividade-Família no espaço doméstico e com a Coletividade-Estado no espaço público.

Observa-se a Coletividade-Estado na intermitente superposição política, cuja liberdade no espaço-tempo intercorporal tem por dominância a normação convencional - contemporânea ou extemporânea, local ou geral - perpassada pelas relações entre corpo e corpo por mando na temporalidade geral do espaço público.

A política mediante força pode ser observada na ação individual e na ação coletiva, tanto na espécie Homo sapiens (humanos na intermitente superposição da Coletividade-Bando), quanto na espécie Pan troglodytes (chimpanzés), e a política mediante mando pode ser observada na ação individual e na ação coletiva, tanto na espécie Homo sapiens (humanos na intermitente superposição da Coletividade-Estado), quanto na espécie Pan paniscus (bonobos na intermitente superposição política da Coletividade-Família por dominância da fêmea alfa), conforme pesquisas demonstrativas de Wrangham e Peterson (1998), carecendo a força e o mando da distinção unidirecional dominante/dominado postulada pelos referidos autores das disciplinas Sociologia, Teoria Política, Direito (Normação), posto que também são observados força e mando em freqüências diversas no sentido dominado/dominante, e sem que aquela "força" alcance o monopólio e a qualidade pretendidos, mesmo que justificada por profissionais legistas.

A insistência desse tópos da "força" como "meio específico (...) a toda associação política" ou nominal Coletividade-"Estado", contudo fenomenologicamente própria da Coletividade-Bando, leva ao paradoxo de ter-se de designar "Estado" uma associação política entre chimpanzés (ver ação típica e similar à política humana em Wrangham e Peterson, 1998: 11-42, 264-266), ou, para adequadamente categorizar tal superposição política, admitir fenomenologicamente que uma associação política autodesignada "Estado", mas que tenha por meio a "força", implica uma real Coletividade-Bando. 
A "força", fenomenologicamente categorizada como ação diádica (Peirce, 1978-1.325: 162-163), exclui a ação triádica própria da Coletividade-Estado, naquela dominando o energético da emoção da Coletividade-Bando, e nessa dominando a ação racional e convencional da real Coletividade-Estado (ver Modesto, 200I). Portanto, a força é própria da Coletividade-Bando, aquela que conflita fïsicamente com a liberdade acausal da Coletividade-Família e com a liberdade convencional da real ColetividadeEstado, ainda que esta coletividade nominalmente travestida de Coletividade-Estado freqüentemente dela se valha, justificada pelo paralogismo das disciplinas citadas.

Cotejar a asserção de dominância da "força", nas idealizadas relações políticas contínuas de dominação, com o cotidiano das relações políticas intermitentes por mando entre pessoas ou coletividades, cuja dinâmica é registrada pela História, é um dos métodos mais elementares para objetar aquela dominância. $\mathrm{O}$ dado imediato para tal cotejamento da intermitência está na própria relação de dominação e suas possibilidades. Conforme descrito por Samuel Johnson, "[n]ão há duas pessoas que possam estar juntas durante meia hora sem que uma assuma uma óbvia superioridade sobre a outra" (Wrangham e Peterson, 1998: 236).

De plano, as relações de dominação não são contínuas como narradas, são intermitências reais, corporais e pessoais como essas descritas por Wrangham e Peterson e estimadas em "meia hora" e secundariamente reais e impessoais, quando introjetamos a consciência da coletividade dominante, ambas na temporalidade do cotidiano, e só excepcionalmente abstratas e coletivas.

As possibilidades fenomenológicas de conduta entre tais pessoas também não são infinitas: entre elas é possível (I) uma "relação" eutímica (comunhão, 3" classe sígnica), possibilitando a exemplaridade, e (II) duas relações políticas (ambas 4i classe sígnica enquanto brutação, ou ação bruta e diádica), uma de mando/acato, possibilitando (II-1) mando casual ou (II-2) mando causal, e (III) outra de força/lesão (ver Modesto, 1999; Peirce, 1978-2.256/257: 147)...Portanto, ou há "relações" simétricas, como na eutimia (calma ou paz em comunhão), ou há relações assimétricas, como na política por mando ou por força, quando, entre aquelas duas pessoas referidas por Wrangham e Peterson, uma assume óbvia superioridade sobre a outra.

A Sociologia, a Teoria Política, e o Direito (Normação), dentre tais "relações" fenomenológicamente possíveis, contudo, selecionam tão só a relação força/ lesão, quando o cotidiano dos humanos observa duas outras relações mais freqüentes, a comunhão eutímica e a política por mando/acato, ambas presentes mesmo que estejamos entre caçadores israelitas e caças palestinos em territórios sob ocupação daquela Coletividade-Bando homicida. Não se nega, portanto, a frequiencia da relação força/lesão - basta ler os jornais -, mas a sua dominância, ad hoc postulada como alta por essas disciplinas para fundamentar um "poder de dominação" e não baixa, como se verifica na sua freqüência histórica.

O outro componente problemático dessas asserções disciplinares está na generalização da "força" nas relações intermitentes de superposição política entre as coletividades dominante e dominada, quando se observa que esse é um meio 
denotativo parcial do macho da espécie, sendo residual na parcela fêmea, que domina por mando (nas suas formas diversas, por amamentação, persuasão verbal ou sedução da imagem). Feitas tais objeções à não demonstrada exacerbação no objeto da política da variável freqüente, mas não dominante, da "força", portanto, qual é o fundamento cognitivo de persuasão para o problema da parcialidade chauvinista nas disciplinas apontadas?

2. Sociologia, Teoria Política, Direito (Normação): Mitologia por fundamento cognitivo

A probabilidade da política por força (4 classe sígnica: Modesto, 1999; Peirce, 1978-2.257: 147), na ação sígnica de persuasão da Sociologia, da Teoria Política, e do Direito (Normação), tem por suporte sígnico na comunicação o interpretante lógico da domestiação (8` classe sígnica: Modesto, 1999; Peirce, 1978-2.261: 148149) expressa no Enuma Elish. A domestiação implica qualquer liberdade indutora das cognições que justificam oscilos, intermitências tais como as da augeridade (liberdade idiossincrásica de uma persona, se cria similaridade desta liberdade, caso do contágio no exemplo), as do mando e da força (brutação), pessoais ou coletivos.

O interpretante lógico da domestiação expressa no Enuma Elish (-XII), texto seminal da etnia akkad, justifica o oscilo da "força". Nessa cosmogonia teogônica de autor ácade anônimo, os deuses primordiais Abzu e Tiamat (ou Tiamtu), respectivamente água doce e água amarga, são personificados e procriam gerações sucessivas de deuses, até que surge um primeiro conflito entre eles. O conflito é banal na Coletividade-Família. Consiste na algazarra que fazem os deuses e que perturba de dia o repouso e à noite o sono do deus Abzu e da deusa Tiamat. (Anônimo akkad, 1994-I-21/28: 47-48)

Sabedores de que Abzu propõe destruir as divindades barulhentas, os deuses tiram a vida do pai dos deuses. (1994-I-30/69: 48-49) Tiamat arregimenta seus asseclas para vingar a morte de Abzu (1994-I-111/162; II-1/48: 50-51; 53/54), enquanto os demais deuses em assembléia escolhem a Marduk, deus de quinta geração da cosmogonia, para fazer frente à ameaça com o mando régio. (1994-II-49/151: 54-57)

Marduk condiciona receber os atributos da realeza à recusa de resolver o conflito com a mãe dos deuses, Tiamat, mediante a política por mando pacífico do "augusto conjuro" (1994-II-J49: 57), preferindo a política por força, uma vez que estava "impaciente por combater (...) [e] pisar prontamente [a nuca] de Tiamtu [ou Tiamat]" (Anônimo akkad, 1994-II-127: 56). Para tanto, é entronizado na politica por mando e mediante ordem sobre todos os deuses, na forma de fixar os destinos por logos fático (verbo-executor) sem ser contrastado:

" Senhor dos deuses, fixador do destino dos Grandes deuses,

Se, como teu vingador,

Vou aterrorizar Tiamtu para salvação nossa, 
Convoca a Assembléia, proclama meu destino transcendente.

Na Sala das deliberações senta-os juntos alegremente,

Faze que minha palavra, no lugar da tua, destine destinos:

Que nada tenha mudança, daquilo que eu determinar,

Que minha ordem proferida seja irreversível, irrevogável'

(...) Quando os deuses, seus pais, viranı o efeito da sua boca,

Saudaram alegremente: 'Só Marduk é rei!'

A ele entregaram o cetro, o trono, a veste"

(Anônimo akkad, 1994-II-154/161; IV-27/29: 57, 66).

A primeira ação política de Marduk é provedora de "ordem" (asharu Anônimo akkad, 1994-VII-123: 88; Lara Peinado, 1994-n.59: 112) no real, implicando sua demonstração de "força" por fato bélico no homicídio da mãe dos deuses, Tiamat, e asseclas. Mediante a "força" do "bem" Marduk destrói o "mal"-Tiamat e a partir de seu corpo cria o Cosmo, estabelece as normas e recebe a homologação do uso da "força" para subjugar resistências no reino da Babilônia celeste, protótipo da nominal Coletividade-Estado Babilônia terrestre. (Anônimo akkad, 1994-I/V: 47-75)

O modelo de Marduk é reiterado na Teogonia - a origem dos deuses - do heleno Hesíodo (-IX). Zeus, deus de segunda geração de deuses, também domina pela "força" o Olimpo, derrotando o pai Cronos. (Hesíodo, 1991) Aristóteles, reiterando Hesíodo e Platão, perfaz o modelo ácade da superposição política por "força" em detrimento do mando, estabelecendo a hierarquia do homem sobre a mulher, seguida da criança, do escravo, e do animal: "a relação entre o homem e a mulher consiste no fato de que, por natureza, um ě superior e a outra inferior, um, governante, outra governada. O mesmo tem que, necessariamente, ocorrer para toda a humanidade. (...) De fato, o homem livre manda no escravo, da mesma forma que o marido, na mulher, $e$ o adulto, na criança" Os "animais distintos do homem nem sequer são capazes de participar da forma sensitiva da razão" (1998-1254b; 1260a; 1254b: 63, 95, 65).

A derivação religiosa dessa mitologia do século XII, vinda do deuscolagem Marduk com seus cinqüenta nomes (Anônimo akkad, 1994-VI-120/122: 80), reiterando a "força" como também referida pelos helenos, foi posteriormente recepcionada pelos hebreus, ao assumirem do ácade ilu o seu dialetal 'el -deus-, na teofederação 'Elohim -deuses-, includente para $Y h w h$, e ao menos outros doze nomes diversos na Torah ("Instrução"). (Motyer, 1986: 157-158)

Podemos encontrar com os hebreus a recepção mítica do macho dominante no B'reshit, primeiro dos cinco livros da Torah, escrito entre $-\mathrm{X}$ e $-\mathrm{V}$ (Garmus, 1992: 25; Mackenzie, 1984: 719 e 720; Fox, 1993: 21), por meio da história ficcional de Abraão, pai das diluições religiosas que reivindicam monoteísmo, como o judaísmo, o cristianismo e o islamismo (Hoff, 1991: 48).

Sua história é "edificante": um pai capaz de "força" homicida contra o próprio filho como fundamento mnemônico de uma nascente e nominal ColetividadeEstado - repugnante para a política bonobo. 'Elohim manda, pondo "Abraão à prova" 
"Deus disse: 'Toma teu filho, teu único, que amas, Isaac, e vai à terra de Moriá, e láo oferecerás em holocausto sobre uma montanha que eu te indicarei" "

Abraão acata. Levantando-se cedo, "selou seu jumento e tomou consigo dois de seus servos e seu filho Isaac. Ele rachou a lenha do holocausto e se pôs a caminho para o lugar que Deus havia indicado. No terceiro dia, Abraão, levantou os olhos, viu de longe o lugar. Abraão disse a seus servos: 'Permanecei aqui com o jumento. Eu e o menino iremos até lá, adoraremos e voltaremos a vós."

Abraão tomou a lenha do holocausto e a colocou sobre seu filho Isaac, tendo ele miesmo tomado nas mãos o fogo e o cutelo, e foram-se os dois juntos. Isaac dirigiu-se a seu pai Abraão e disse: 'Meu pai!' Ele respondeu: 'Sim, meu filho!'- 'Eis o fogo e a lenha, retomou ele, 'mas onde está o cordeiro para o holocausto?' Abraão respondeu: 'É Deus quem proverá o cordeiro para o holocausto, meu filho', e foramse os dois juntos.

Quando chegaram ao lugar que Deus lhes indicara, Abraão construiuo altar, dispôs a lenha, depois amarrou seu filho e o colocou sobre o altar, em cima da lenha. Abraão estendeu a mão e apanhou o cutelo para inolar seu filho" (Moisés, 1985-1.22,1-10: 59-60).

Na constituição de uma nominal Coletividade-Estado essa fabulação da potência (possibilidade) de "força" no limite homicida de rompimento com a Coletividade-Família, que alinha Marduk, 'Elohim ou Yhwh ou ..., Zeus, pressuposto de Aristóteles (1998-1286b: 255), de Jellinek (1954:320, 322), de Weber (1980: 1056), implica domestiação, posto induzir o receptor a uma experiência virtual de força/lesão ou mando/acato, que por ser relação referencialmente ficta e não indicial, tranqüiliza as resistências liminares do receptor, probabilizando suas justificativas posteriores a experiências reais de relação força/lesão ou mando/acato, que envolvam terceiros.

A domestiação (8 $8^{\mathrm{a}}$ classe sígnica: Modesto, 1999; Peirce, 1978-2.261: 148-149), pela eutimia de um texto oral ou escrito, o Enuma Elish, a Torah, a Teogonia, induz o receptor a uma cognição sem experiência real de mando e acato ou de força e lesão (4a classe sígnica: Modesto, 1999; Peirce, 1978-2.257: 147), justificando o acato e a lesão e contagiando o receptor com os interesses do emissor de eventuais mando ou força, formando suas expectativas mnemônicas.

Por domestiação prepara-se cognitivamente o receptor para a ação política que rompe as qualidades eutímicas da Coletividade-Família - como visto com os mitos de ácades, gregos, hebreus -, subjugando tais qualidades à política por mando ou força da Coletividade-Bando, ou fundamentando a convencionalidade na política por mando da Coletividade-Estado, dominada pela reivindicação de representação (Modesto, 1994). Em plena Idade do Ferro (-XV a -I), os referentes textuais derivados de Marduk, 'Elohim ou Yhwh ou ..., Zeus, criam na memória das Coletividades essa previsibilidade perversa, cruel e repugnante da "força" estetizada pela mitologia, pelas derivações religiosas tribais, e justificada pelo conhecimento comum da Sociologia, da Teoria Política, e do Direito (Normação).

Essa é a domestiação mítica que fundamenta a relação dominante/ 
dominado nas culturas ocidentais, "o" "homem" a "força" do macho nos limites do homicídio, do rompimento com a Coletividade-Família, o modelo ácade renovado por hebreus e por gregos.

A qualidade estética do mito, a sugestão emocional da força, persuasiva e religiosamente capeada faz-se tão verosímil e vigorosa que Aristóteles, Jellinek, Weber dispensam-se de demonstrar historicamente suas hipóteses da "necessária posse de força", "da força dotando a dominação de direito", ou "do Estado definido pela força" A variável da "força", contudo, é historicamente reducionista para sustentar uma relação de dominação, ainda que possa ser o seu "boot", mas é emocionalmente rica na sugestão de ameaça reproduzida por via do ensino regular que aquelas disciplinas - com pretensão de neutralidade - emprestam à ação política, retirando delas a distância crítica que uma observação fenomenológica permite empregar.

\section{Entre bonobos e chimpanzés: humanos?}

Conforme observado, os modelos teóricos das disciplinas Sociologia, Teoria Política, Direito, cujo objeto implica a políitca, referem " $o$ " "homem" nos moldes gregos do anthropos nomos de Protágoras (-V) como "medida de todas as coisas" (Platão, 1990-21.177c: 917; 166b/167d: 909; 1990-28.716c: 1340), trazendo o corte mutilador deste objeto com a "força" do homem, e ocultando o seu complementar oposto do mando reprodutor da mulher, nos extremos complementares de suas características biotípicas que fundam suas respectivas superposições políticas, nas suas formas diversas, por amamentação, persuasão verbal ou sedução da imagem.

Tomar os humanos na política pela espécie "o homem" como vimos, reduz o objeto e vicia seus argumentos, assim referidos - por mera indulgência - aqueles topoi meramente opinativos de Aristóteles, Jellinek e Weber. Retomar os humanos pelo gênero "do humano" que oculta "ạ fêmea" é cientificamente objetável, face à notória alta frequêencia do macho na política por mando, e face ao fato de a domestiação dos machos sobrelevar o perfil (contingência ambiental do corpo Modesto, 1998: 196), o papel (a ação) e o status (o prestígio) do macho.

Por outra, desconsiderar a inarredável conduta animal dos humanos, fundados na suposta hierarquia aristotélica entre humanos e demais espécies animais (1998-1253a: 55-56; 1254b: 65), implica negligenciar cientificamente dados comuns da animalidade na conduta política dos humanos relativamente aos integrantes da família hominidæ, encobrindo o aspecto estacionário da "força", desconsiderando o aspecto evolutivo do "mando", e até mesmo a percepção ancestral dos humanos que tomam os chimpanzés como irmãos da mesma família (Fouts, 1998: 58-59).

Para re-compor tal objeto mutilado por aquelas disciplinas, observaremos por meio da Hominilogia (Hominilogy) a família hominidæ (bonobos, humanos, chimpanzés, gorilas, orangotangos), fundamentados na comunhão de identidades genômicas com humanos que vai de 98,4 com chimpanzés, passa por 97,7 com gorilas, até 96,4 com orangotangos (Fouts, 1998: 65-66), permitindo observação comparativa 
relativamente aos padrões de civilidade (civility) da família na ação política, enquanto mando ou força (tïg. 2).

A Hominilogia, ciência que tem por objeto a família hominidæ, permite um corte epistemológico não-hierárquico e composto, envolvendo o par complementar fêmea-macho da família, com as características biotípicas dominantes que suportam as respectivas e distintas superposições políticas, possibilitando selecionar sem mutilação e para observações comparativas (1) os bonobos (pela civilidade - civility), (2) os humanos (pela pré-civilidade - pre-civility), e (3) os chimpanzés (pela incivilidade incivility). (Modesto, 1999)

Para tais observações comparativas, partiremos das variáveis comuns da conduta (5i classe sígnica: Modesto, 1999; Peirce, 1978-2.258: 147) objetiva do par complementar fêmea-macho na família hominidæ, que designamos mediante o signo comum de dois gêneros hominida (conforme Modesto, 1999). A família hominida será aqui observada por suas relações eutímicas, na comunhão, e políticas, na superposição por mando/acato ou força/lesão, quantificáveis como civilidade, para efeitos de controle científico (verificação e demonstração), aplicando o Modelo da Superposição Política (Modesto, 1994, 1999).

O signo civilidade implica recepção por contágio (na imitação), assimilado (na reiteração) e acomodado (na expectativa), de condutas por convívio coletivo a partir da imediatidade das relações mãe-cria, pai-cria, e fêmea-macho, independente de transmissão formal ou normação por mando. A denotação desse signo, a sua implicação qualitativamente existencial, surge empregada aproximadamente nesse sentido no século XVI, quando a educação formalmente transmitida não havia sido implantada como a conhecemos hoje, e sem a sintaxe com a normação imputável que o signo "civil" eventualmente inclui no espaço público. (cotejar Ariès, 1981: 243, 240, 245; ver domestiação em Modesto, 1999; ver Piaget, 1978: 19-47)

A civilidade, como observada pela Hominilogia, pode ser descrita pelas formalidades comunicativas de conduta na família bonobo, humana e chimpanzé, por meio de signos dominantes, freqüentes, ou residuais da comunhão (na relação eutímica), do mando e da força (na relação política). O grau de civilidade na conduta hominida, portanto, implica dominância da comunhão, seguida da freqüência do mando, e por último resíduo de força. À medida em que a dominância se desloca para a força, temos a incivilidade. Com a freqüência da força em alternância com o mando, temos a précivilidade.

\begin{tabular}{|c|c|c|}
\hline INCIVILIDADE & PRÉ-CIVILIDADE & CIVILIDADE \\
\hline $\begin{array}{l}\text { chimpanzés } \\
\text { (Pun troglodytes) }\end{array}$ & $\begin{array}{l}\text { humanos } \\
\text { (Homo supiens) }\end{array}$ & $\begin{array}{l}\text { bonobos } \\
\text { (Pan paniscus) }\end{array}$ \\
\hline $\begin{array}{l}\text { frequêencia do imando } \\
\text { dominância da força }\end{array}$ & $\begin{array}{l}\text { alternância do mando } \\
\text { frequiência da força }\end{array}$ & $\begin{array}{l}\text { dominância do mando } \\
\text { resíduo de força }\end{array}$ \\
\hline
\end{tabular}

Figura 2 - Padrōes de civilidade da familia hominidæ na Politica (mando e força) 
Nesse caso, a civilidade na comunicação pode ser descrita como modelar nos bonobos, ou Pan paniscus, pela dominância da comunhão eutímica e do mando; a pré-civilidade nos humanos, ou Homo sapiens, pela alternância do mando (similar à política bonobo bonobo politics) com a freqüência da força (similar à política chimpanzé - chimpanzee politics); e a incivilidade nos chimpanzés, ou Pan troglodytes, pela dominância da força.

Nossos familiares bonobos, na dominância política por mando, comunicam-se mediante bramidos curtos, agudos e suaves, com alcance de pequena distância territorial; nossos familiares chimpanzés comunicam-se mediante enormes berros guturais, grunhidos e latidos de grande distância territorial (Wrangham e Peterson, 1998: 251); os humanos, por sua vez, com a modulação fonética codificada e o auxílio de suporte material, implementaram de tal modo a política por mando, que é possível recepcioná-lo a qualquer distância territorial no mercado mundial mediante variável suporte material e sem sintaxe temporal com o corpo emissor, haja vista o alcance por domestiação da mitologia ácade do Enuma Elish (-XII) nas disciplinas apontadas.

No uso de ferramentas, comum em 2 milhões de anos na familia hominicla (bonobos, humanos, chimpanzés), o índice de força é encontrado no arrastar de galhos na política bonobo e chimpanzé (1998: 82 e 258), chegando ao paroxismo da bomba atômica do genocida estadunidense Harry Truman contra japoneses em Hiroxima e Nagasaki com matança total de 150 mil humanos em 1945, uma política chinupanzé elevada à demência serial killer.

Ao contrário da pré-civilidade dos humanos, a política bonobo reduziu seu uso de força ao residual nas relações intercorporais entre sexos, entre pais e filhos, intra ou entre coletividades (Wrangham e Peterson, 1998: 264, 252-253), enquanto os chimpanzés e humanos são similares nas surras contra fêmeas e filhos, no estupro de infantes ou adultas, incluindo dilacerações in vivo. Nos bonobos não há registro de sexo forçado, surras e morte dos filhos, como freqüente entre humanos e chimpanzés.

$\mathrm{Na}$ relação entre coletividades de bonobos é igualmente registrada a ausência de superposição política por força, dominando a comunhão eutímica, que tem no prazer erótico, independente da reprodução, o meio de comunicação, hetero ou homossexual, entre pares ou na diplomacia entre coletividades, ou o mando naqueles tons curtos, agudos e suaves. Suas relações implicam cooperação coletiva e solidariedade entre fêmeas, não entre machos, cujos mandos são colocados na periferia da política, e os filhos machos permanecem inseparados das fêmeas durante toda a vida. Se um macho ataca uma fêmea, essa solidariedade coletiva entre fêmeas repele a força (Wrangham e Peterson, 1998: 251, 253-254, 26I-262, 271).

A solidariedade entre as fêmeas bonobos tem por elemento vinculante o prazer homoerótico. O apoio da mãe, enquanto viva, acaba sendo relevante na competitividade política por mando que resulta no macho alfa, o dominante entre os machos. Na morte da mãe, decai sua dominância. Disso decorre a quale feminina como referência política e a co-dominância política entre a fêmea alfa, suportada pela cooperação coletiva das fêmeas, e o macho alfa na coletividade, sem o suporte da 
cooperação por força dos machos. (Wrangham e Peterson, 1998: 252, 256-257) A característica da civilidade na política bonobo, portanto, pode ser resumida pela dominância da eutimia, fundada no erótico, na vitaliciedade das relações mãe-cria, na comunhão entre fêmeas, e a superposição política, quando existente, tem predominio do mando, enquanto a força é residual na co-dominância entre fềmea e macho.

\section{Formas de "Direito" (Normação): berro ou homicidio e matança?}

Entre chimpanzés e humanos dominam as similaridades políticas (Wrangham e Peterson, 1998: 158, 181) do mando, degradado no berro, e da força, degradada no homicídio e na matança. Em ambas as espécies pode-se observar o mando feito aos berros guturais e grunhidos de grande distância, em função da posição alfa direcionar-se para predações de alcance territorial território (1998: 206, 217, 229, $230,266)$.

Entre familiares humanos a relação entre mãe e cria é reduzida ao período da amamentação (Montagu, 1988: 90), ou limitada à infância. Não há solidariedade entre fêmeas, preferindo estas os efeitos de prestígio dos machos avezados à força (1998: 292-295) e quando há cooperação, ela se reduz aos machos, ou entre pai e fïlho (1998: 205), exacerbando-se na superposição política por força nos policiamentos ou nas matanças por homicídio bélico.

Nos humanos, em razão da modulação fonética codificada, a superposição política por mando é mais freqüente relativamente à comunhão eutímica, e nesta o sexo é controlado (Akoun, 1983: 245) e feito em função do macho, admitindo-se só recentemente e em reduzidas regiões geográficas do planeta a eutimia na partilha do prazer com a fêmea, em realidade, uma conquista dessa, havendo até mesmo práticas buscando limitar a eroticidade (Wrangham e Peterson, 1998: 139), que exemplificamos na circuncisão entre judeus (Markert, 1989: 112-113), ou como na clitoridectomia entre negros africanos (Akoun, 1983: 128).

No extremo da política chimpanzé (naquilo que é comum a humanos e chimpanzés, na respectiva dominância e freqüência da incivilidade com a incidência da força), a pré-civilidade dos humanos apresenta taxas gerais de homicídios intergrupais entre 5 e 65 em cada 100.000 pessoas por ano $(0,005 \%$ a 0,065\%), desde a Grécia antiga até o presente (Wrangham e Peterson, 1998: 305). Entre brasileiros a expressão numérica da política chimpanzé com a força por homicídio e por lesão corporal implica respectivamente 11.706 e 1.795 humanos $(7,7 \%$ e 1,2\% numa coletividade encarcerada de 152.709 indivíduos - 95,5 presos por 100.000 habitantes -Justiça, 1996: 33, 15). Projetando-se aqueles números para as variações anuais da população mundial, podese obter o índice da pré-civilidade humana que, como se observa, é freqüente, mas não dominante.

Essa pré-civilidade dos humanos potencializou a força singular na força serial, um modo de produção homicida designado "guerra" Para essa produção e 
reprodução homicida justificada por normóide (simulação normativa), os humanos criaram o recrutamento compulsório, uma forma de escravidão - hoje circunscrita no tempo à mutilação da Coletividade-Família com a expropriação do adolescente em que machos mais velhos adestram machos jovens e imberbes mediante valorizados berros guturais para a incivilidade chimpanzé, que vai da insensibilização para vilezas da simulação, dissimulação ou mentira, ao homicídio, decidido dominantemente por gerontocratas estéreis, terroristas para a política bonobo, como Harry Truman (Estados Unidos da América do Norte), Adolf Hitler (Alemanha), Mao Tsé-Tung (China), Pol Pot (Camboja), Slobodan Misolevic (ex-Iugoslávia), Ariel Sharon (Israel), Saddam Hussein (Iraque), Stalin (ex-União das Repúblicas Socialistas Soviéticas), George Walker Bush (Estados Unidos da América do Norte) ...

A "guerra" reivindicada como "uma forma de direito" contudo um decaimento fenomenológico da convenção por mando para o conflito por força na comunicação, implica Coletividade-Bando, contudo foi assimilada às atividades comerciais no mercado e na "busca de prestígio" (Akoun, 1983: 246, 248, 250), quando uma coletividade se afirma perante outras mediante o homicídio bélico, modulando-o no adestramento para o policiamento territorial armado, exacerbado no militarismo contra coletividades intraterritoriais, caso da etnia brasileira a partir de 1964 com suas polícias militares, superpostas em moldes bélicos contra a população civil, caso da Polícia Militar do Estado de São Paulo, sob o mando do preposto local Geraldo Alckmin.

No ano de 2002 essa Coletividade-Bando travestida de ColetividadeEstado matou 610 civis, "o maior número desde que as estatísticas começaram a ser produzidas, em 1966 (...) um aumento de 32,8\% nos óbitos [em relação a 2001 ], segundo dados oficiais da Secretaria da Segurança Pública de São Paulo". É "sintomático que menos civis tenham saido feridos dos enfrentamentos. Em 2002, eles foram 420, contra 459 no ano anterior. Isso significa que a polícia também está se tornando mais letal. (...) Para efeitos de comparação [com outra Coletividade-Bando], as instituições policiais dos EUA, juntas, mataram 297 civis ao longo de 2000. Nesse mesmo ano, a polícia paulista matou praticamente o dobro: 595. O detalhe é que a população dos EUA é sete vezes maior do que a de São Paulo" Agrava saber que esse índice da política chimpanzé do modo de produção homicida na busca de prestígio integrou as promessas de campanha dos candidatos nas eleições de 2002, Paulo Salim Maluf (PPB), José Genoíno (PT) e o eleito Geraldo Alckmin (PSDB): "bandido bom é bandido morto" (Paulo, 2003-a: A2)

As matanças por homicídio bélico territorial ou extraterritorial reivindicadas como "uma forma de direito", caso da etnia estadunidense, com o precedente hierático do tipo mando-casual, chegam a respaldar-se na pseudoneutralidade normativa da Organização das Nações Unidas (ONU) e na utilização da fïlmagem de seus serial killers em ação bélica para venda da própria tecnologia homicida, além de investir no potencial homicida humano, cooptando adolescentes em revistas especializadas ou mediante videogames com sons baseados em combates reais oferecidos gratuitamente pela internet objetivando treiná-Ios para homicídios bélicos (Roos, 2002: 22). Por meios 
bélicos variados, observa-se a política chimpanzé também no canibalismo, na mutilação do corpo das vítimas, na redução de cabeças, resultando "desagregação e até mesmo, por vezes, o desaparecimento de culturas inteiras" (Akoun, 1983: 249).

A reivindicação da guerra como forma de "direito" é amparada por normóide simulando a espécie lex in genere na Carta das Nações Unidas (ONU) de 1945 , que, a despeito do propósito de "[m]anter a paz e a segurança internacionais" (art. 1), não exprime nos princípios expostos no artigo 2 a seqüência lógica daquele propósito, no que seria o desarmamento de todas as Coletividades-Estado como condição objetiva de realização da paz. Ao contrário. Na seqüência ilógica para a paz, com o sentido de "habilitar as Nações Unidas na tomada de medidas (...) urgentes" a Carta manda armar, pelo que (art. 45) "os Menbros deverão manter, imediatamente disponiveis, contingentes das forças aéreas nacionais para a ação combinada de coerção internacional" (Nations, 2002)

Desarmar não implica uma qualidade positiva para essa espécie normóide, como se infere do art. 1, ao contrário, designa a qualidade negativa da sanção (arts. II e 47). É bélica a disposição dominante da Carta das Nações Unidas, exortando retoricamente uma única e isolada vez (art. 2) que as Coletividades-Estado não envolvam força armada para efetivar as decisões do Conselho de Segurança (art. 41). (Nations, 2002)

O uso preferencial da "força" (force) no documento é garantido e reiterado por freqüentes e sortidos dispositivos, que mencionam as suas modalidades: armed force (preâmbulo), enforcement action e enforcement measures (art. 2), enforcement action (art. 5), air, sea, or land forces (art. 42), armed forces (art. 43), force (art. 44), air-force e enforcement action (art. 45), armed force (art. 46), forces (art. 47), preventive or enforcement measures (art. 50), enforcement action (art. 53), volunteer forces (art. 84). (Nations, 2002)

O modelo da Carta, além da relação autocrática do Conselho de Segurança relativamente à Assembéia-Geral (artigos 10,11,24, 27) implicar déficit democrático (Modesto, 1997-b), é de força (yang) e não de mando (yin), também implica suspeição (yang) sobre todas as Coletividades-Estado e não reação por mando, via negociação e mercado (yin), referentemente a suas eventuais relações problemáticas. Nesse caso, sua asserção de manutenção da paz é ilógica na forma e cínica na conduta. Refreia o uso da força, tomando contudo a iniciativa da força. Concerta meios pacíficos por meios inadequados de força.

A "organização de seus membros" (o conjunto de nominais Coletividades-Estado) é administrada por normóide autocrática (para bellum - "prepara a guerra" ocidental) e não por normação comunial (wu wei - "vago fazer" implicando o "pu cheng - sem lutar" oriental - item 6), preferindo a ocidental lógica excludente do homicídio das Coletividades-Bando à oriental lógica includente da negociação apropriada às Coletividade-Família e Coletividade-Estado, exprimindo típica conduta política chimpanzé em detrimento da política bonobo.

Desde os primórdios da escrita com a etnia han (chineses), passados 9.000 anos, a "grande" obra política do homo sapiens é a Carta das Nações Unidas 
(ONU). O modelo da Carta, contudo, funda-se em mitos dominantemente ocidentais e excludentes (item 2), traindo sua pretensão de universalidade e inclusão, próprias da civilidade bonobo, para expressar a incivilidade da política chimpanzé com o uso e valorização da força.

Os padrões de homicídio bélico entre as concorrentes ColetividadesBando no mundo de hoje, reforçados e justificados na Carta das Nações Unidas, superaram as antigas delimitações de campo de combate entre profissionais homicidas mutuamente identificados por farda. Eram homicídios bélicos de conquista nas fronteiras, quando hoje são homicídios separatistas, conflitos internos, e mesmo guerrasnegócio, caso da Coletividade-Bando estadunidense impondo os seus produtos altermentes (medicamento $\cong$ alimento $\cong$ "droga") no mercado mundial (alcoóis, tabaco, Prozac, Dormonid ... ) e buscando suprimir os consumos concorrentes das ColetividadesFamília Colômbia (cocaína), Mianmá (heroína), Brasil (cannabis), mediante investimentos em tecnologias de homicídio bélico. (Modesto, 1994)

O homicídio bélico e o medo, hoje ocorrem no meio da população civil, muitas vezes sem a identificação fardada dos combatentes, outras tantas sem atinar a origem das bombas demolidoras, caso da invasão de George Walker Bush e sua Coletividade-Bando do Iraque em 2003, podendo graduar-se no terror, descrito este como o transbordamento da força bélica de Coletividades-Bando para exaltar o medo da Coletividade-Família, possibilitando acompanhamento da janela de um apartamento urbano, enquanto o observador não tombar por uma bala perdida.

Invertem-se as expectativas de morte, finando menos combatentes da Coletividade-Bando travestida de Coletividade-Estado e mais civis, mulheres e crianças da Coletividade-Família especialmente, designados eufemisticamente "danos colaterais". (Veja, 2002-1.751: 33) "As mortes acidentais de civis em tempos de guerra aumentaram de 5 por cento, no início do século XX, para 15 por cento durante a Primeira Guerra Mundial, passando para 65 por cento ao final da Segunda Guerra Mundial, e chegando a mais de 90 por cento nas guerras do final do século XX" (Fund, 2002)

Nas forças armadas, admite-se até mesmo o homicídio entre combatentes ou civis da mesma etnia, quando a estratégia serve para os efeitos publicitários de imputar ao inimigo determinada atrocidade, ou quando o "fogo amigo" entra nos cálculos do mal menor.

A indústria do cinema, particularmente a de Hollywood, por vezes oferece a idéia homicida envolvendo outras etnias e a população civil estadunidense também colhe os resultados. A ciência até alcançou a percepção de que há cicatrizes no uso da força reduzida às "inofensivas" palmadas na infância (Teicher, 2002), contudo o conhecimento comum dos notáveis da etnia brasileira das comunicações admite a força da "palmada [como sendo] até justificável" (Veja, 2000-1.673: 94).

No mercado da morte, com dados anuais de 1994, conforme Instituto Internacional de Investigação da Paz, (1) a Coletividade-Bando estadunidense é líder na exportação de armas, com 11,9 bilhões de dólares, seguida das (2) Coletividades- 
Bando Alemanha (3,1 bilhões de dólares), (3) Inglaterra, (4) China, (5) Rússia e (6) Brasil (61 milhões de dólares) (Veja, 1995-1.397: 45).

A primeira, terceira, quarta e quinta Coletividades-Bando referidas pelo Instituto Internacional de Investigação da Paz são membros permanentes do Conselho de Segurança da ONU, prontos para "oficialmente" implicar guerras - matanças entre nominais "Coletividades-Estado" e reais Coletividades-Bando -, ou "inoficialmente" implicar terror e mercadejar tecnologias homicidas, justificando a política chimpanzé mediante resoluções auto-coonestadoras fundadas no implemento homicida ("para bellum") como intrumento para a paz ("si vis pacem") no Planeta Terra; a última Coletividade-Bando supra referida Brasil foi uma postulante à partilha homicida com Fernando Henrique Cardoso.

Quando se observa, diferentemente da força homicida serial na guerra, a força homicida singular entre coletividades de um mesmo território, a pré-civilidade humana mantém-se no mesmo padrão de dominância do macho homicida da política chimpanzée, e o índice dessa asserção extensível ao mercado mundial encontramos nos estadunidenses, "sociedade notória (entre as nações industrializadas) por seu alto indice de assassinatos" (Wrangham e Peterson, 1998: 104). O adestramento estadunidense para homicídios extraterritoriais é tão produtivo, que já está em fase de autofagia, volta-se contra a própria etnia, casos de Timothy James McVeigh em Oklahoma em 1995, e George Walker Bush no Texas de 1995 a 2000 (ver item 6).

\begin{tabular}{|c|c|c|c|}
\hline \multicolumn{4}{|c|}{ INTERVENÇÕES OU GUERRAS INTERNAS E EXTERNAS DA COLETIVIDADE-BANDO EUA } \\
\hline \multicolumn{2}{|c|}{$\begin{array}{c}228 \text { ANOS DE } \\
\text { INDEPENDENNCIA }\end{array}$} & $\begin{array}{l}168 \text { ANOS DE } \\
\text { CONFLITO }\end{array}$ & ALCANCE DA COLETIVIDADE-BANDO EUA \\
\hline $1775-1783$ & (09) & 08 & Guerra de Independência (América do Norte) \\
\hline $1798-1801$ & $(04)$ & 04 & Guerra naval com França \\
\hline \multicolumn{4}{|c|}{ SÉCULO XVIII: II ANOS DE CONFLITOS } \\
\hline 1801-1805 & $(05)$ & 04 & Campanha contra piratas berberes (África do Norte) \\
\hline $1812-1814$ & (03) & 0.3 & Guerra com Canadá \\
\hline 1812-1814 & $(03)$ & & Guerra com Grã-Bretanha (América do Norte) \\
\hline $1820-1859$ & (40) & 40 & Campanha contra índios no leste e no sul (América do Norte) \\
\hline 1831 & (01) & & Desembarque nas Ilhas Malvinas \\
\hline 1832 & $(0 \mathrm{I})$ & & Campanha contra piratas na Malásia \\
\hline $1835-1836$ & $(02)$ & & Guerra contra México \\
\hline $1846-1848$ & $(03)$ & & Guerra contra México \\
\hline 1852 & $(0 I)$ & & Desembarque em Buenos Aires \\
\hline 1854 & $(01)$ & & Desembarque na Nicarágua \\
\hline $1856-1860$ & $(05)$ & 01 & Campanha no Panamá \\
\hline 1856 & $(0 \mathrm{l})$ & & Intervenção em Cantão (China) \\
\hline $1861-1865$ & (05) & 05 & Guerra de Secessão (América do Norte) \\
\hline $1861-1880$ & (20) & 15 & Campanha contra índios no oeste (América do Norte) \\
\hline 1871 & $(01)$ & & Intervenção na Coréia \\
\hline 1882 & (01) & 01 & Intervenção em Alexandria (Egito) \\
\hline
\end{tabular}




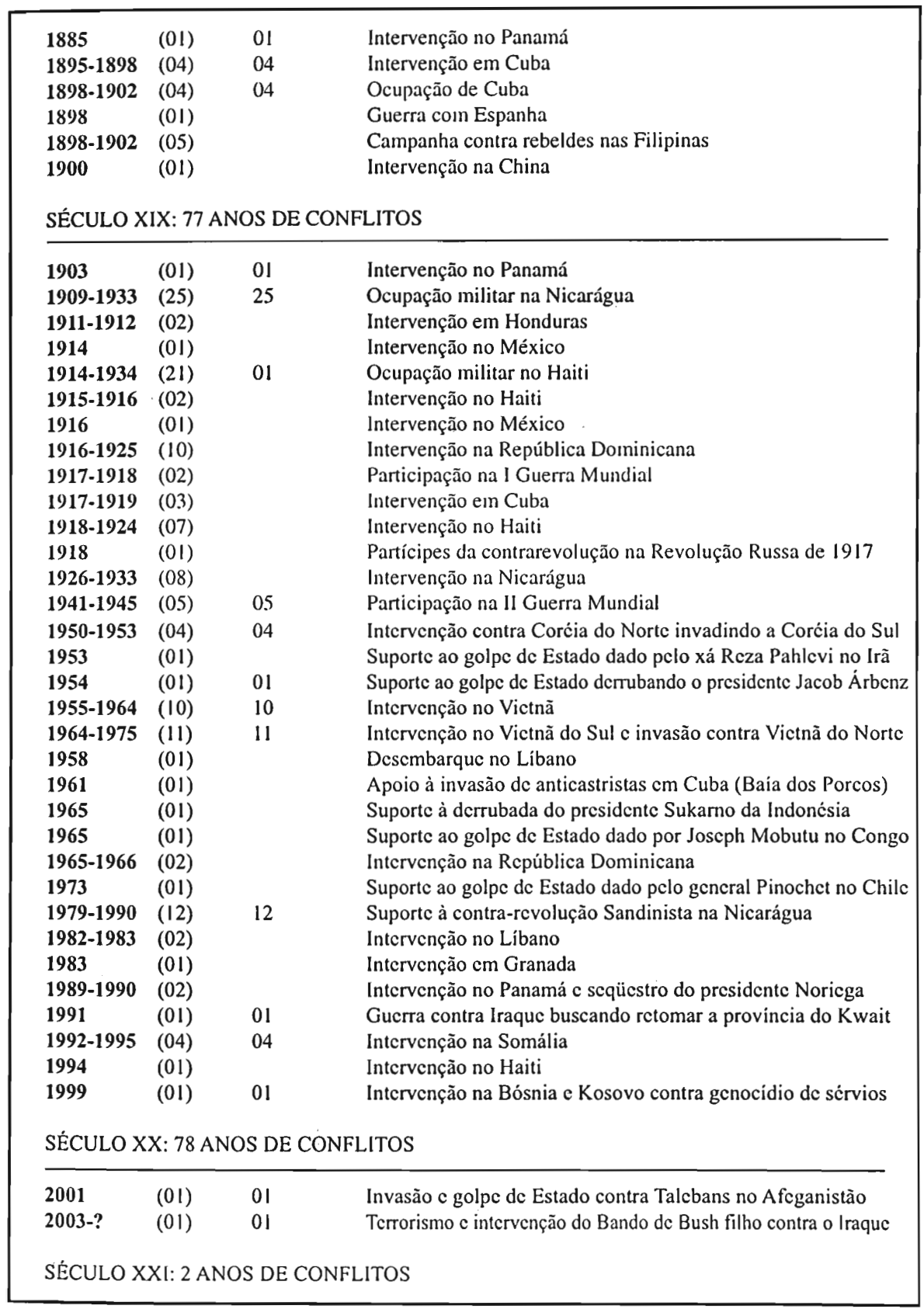

Figura 3 Dislate ou dislogia étnicos: 1 intervençào ou guerra a cada 1,3 anos pelo mundo 
Tal adestramento do macho para o homicídio vem lastreado em crença messiânica numa difusa "missão universal": a "aplicabilidade universal dos valores [norte-] americanos (Kissinger, 1996: 581, 582). Assim, qual hiena, que marca o território mediante miç̧ão, a Coletividade-Bando estadunidense deixa o cheiro do sangue pelo mundo mediante freqüentes homicídios bélicos. Dislate ou dislogia étnicos, a politica chimpanzé estadunidense semeia o ódio e colhe o medo. O mercado mundial cobra o preço. A incivilidade pode ser contabilizada. Em 228 anos de independência (1776 a 2003) e democracia simulada, a nominal Coletividade-Estado EUA superpôsse como Coletividade-Bando durante 168 anos, ou seja, 1 intervenção ou guerra a cada 1,3 anos pelo mundo, conforme fig. 3 (Bonalume Neto, 1991; Lincoln, 1978; Microsoft, 1998; Veja, 1995-1.361; Larousse, 1995-24; Larousse, 1995-9: 2.241; Rohter, 1994: 12; Sanger: 2003: A16).

É evidente a política bonobo da mulher no uso residual da força, "porém, em toda parte, como uma tendência globalmente consistente, o gênero da população criminosa corresponde de modo previsivel à violencia do crime. Os criminosos do sexo masculino se especializaram em crimes violentos. Nos Estados Unidos, por exemplo, a probabilidade de que um homem cometa assassinato é nove vezes maior do que uma mulher" (Wrangham e Peterson, 1998: 142-143). Entre brasileiros seria diferente? Caro receptor, por experimentação, colecione um mesmo jornal por dez dias seguidos, verificando e anotando qual sexo predomina nos homicídios noticiados. A probabilidade do masculino superar o feminino é estatística.

Em que pesem as similaridades entre chimpanzés e humanos na política por força, seguindo o mesmo experimento, também se pode observar entre humanos a predominância da política por mando, na diversidade das formas de normação, relativamente à política por "força". Uma vez que fenomenologicamente a força não se inclui na categoria físico-semiótica da normação, aquela reivindicação da força, que se degrada no homicídio e na matança, se reivindica "uma forma de direito" como pretendido por Akoun (1983: 246, 248, 250), implica uma simulação normativa ou normóide, não passando a designação formal da espécie normativa (dharma, fa, fiqh, law, constituição, lei, decreto etc.) de mero eufemismo dissimulador da brutação e justificação prévia da política chimpanzé para a superposição política das ColetividadesBando no Planeta Terra.

\section{Teorias de Estado: opção chimpanzé}

A Normação entre dominantes e dominados humanos múltiplas ações normativas por exemplaridade, por mando-casual e por mando causal (Modesto, 1997-a) movidas por multívocos interesses na relação mando/acato observadas por diversas espécies no mercado mundial -, é dominada pela entropia (quantidade de desordem), conflito interpretante entre as Coletividades Família, Bando, Estado, em seus respectivos territórios.

Em que pese a entropia na normação entre dominantes e dominados de um território, observa-se diacronicamente freqüente a conciliação normativa. 
Conciliação normativa não implica qualidade acreditada intrínseca da dominação ou do mando, como se crê por exemplo com o signo "legitimidade" mas qualidades similares na relação do acato com o mando crivel, mando cujo objeto seja eutímico (pacifico) e não implique simulação ou dissimulação de seu interesse. O mando crível suporta o acato irrefletido no contágio e reitera-se por acato refletido nas expectativas mnemônicas, contudo amplia aquela entropia no acato resistido.

No mercado mundial, os conflitos normativo-interpretantes são indiciados por sua disparidade de formas para aqueles multívocos interesses, nenhuma delas dominante no planeta, como: dharma, artha, kama nas coletividades hindus; $s h i h$ (式- exemplo), li (禮- rito), $f a$ (法- modelo) nas coletividades han (chineses); figh entre muçulmanos; lex in casu entre anglo-saxões; e lex in genere.

A lei-gênero é conceito criado entre coletividades romanas ao final (séc. -I) de sua República (-509 a -27) e começo do império, seguida pelos italianos, franceses, germanos, espanhóis e etnias latinas em geral, incluído o império português. O mando normativo, por meio da espécie lex in genere, hoje designado "Direito" por essas etnias romanísticas do Lácio, é signo ambíguo para a Dogmática Jurídica e a Teoria Jurídica mando e justificação política.

Foi por meio dessa Teoria Jurídica que a política chimpanzé dos humanos construiu, fundamentada na força de sua parcela macho e exclusão da paz de sua parcela fêmea -, um dos conceitos de "Estado" para as diversas Teorias de Estado. A ambigüidade do conceito, portanto, é congênita para as singularidades do caso (a força e as armas) e do gênero (o mando e os códigos verbais, na fala ou no registro).

Cada Coletividade-Etnia, em função de sua normação singular, constrói o seu conceito de "Estado" como entre ocidentais, ou dispensa-se dessa construção, caso da etnia han e suas adjacências (cotejar Kissinger, 1996: 543). Os han e adjacências relevam o corpo na contigüidade étnica 國 kuo, nação e depreciam a continuidade do mando formal administrativo 王 wang, monarca, governar (cotejar Lao Tzy, inédito-32;57). O oriental observa a impossibilidade denotativa no referente ocidental de "Estado" Assim, cada dinastia, cada escola (chia) pontua sua cronologia e a cronologia continente tem base étnica e registro histórico com a dinastia Shang (-XVIII a -XII), sem se reduzir a ela (cotejar Mateos et alii, 1977-III: 131).

O signo "Direito", quando referido - e não-subsumido - a essa diversidade da Normação (ação de vincular um legisigno, ou signo de lei na espécie dogmática, a uma conduta subjugada) no mercado mundial implica o erro lógico de designar o gênero por uma de suas espécies, como visto no item 1.

O conceito de "Estado" - naquela tradição em que domina a lex in genere, em relação à lex in casu -, toma por base uma estrutura de força-poder (Gewaltstruktur), no sentido de monopólio da força, considerando-a como violência legítima (Müller, 1998: 99), na exaltação da força, não da paz, um índice de que a Teoria Jurídica é construída por machos e valorizando a dominância do macho similar da politica chimpanzé. Nesse passo histórico, é curioso observar a afinidade diacrônica entre os textos de Akoun, Wrangham-Peterson, e Hobbes. 
Esses textos expõem a ausência de distância crítica apontada nos itens 1 e 2, tanto da Teoria Politica, quanto da espécie Direito, no particular das Teorias de Estado, resignadas ao conhecimento comum e justificador da força, própria à testosterona de metade da espécie dos humanos, excluindo a politica estrogênica da paz desarmada ou politica bonobo (item 6), um critério parcial e impróprio para uma generalização científica que a teoria intenta com a designação "Estado"

Para Hobbes, na tradição do mando-casual do tipo étnico anglo-saxão, "[e]m todos os lugares onde os homens viveram enquanto pequenas Familias, roubar e espoliar um ao outro sempre foi ato de Comércio, e assim, longe de ser reputado contra a Lei de Natureza, quanto maior a espoliação ganha, maior era a honra; os homens não observavam nenhuma outra Lei senão a Lei da Honra; vale dizer, privavamse da crueldade, deixando aos homens suas vidas e instrumentos de agricultura. Tal como faziam então as pequenas Familias, assim fazem hoje as Cidades e os Reinos, que nada mais são do que Famílias maiores que, para a própria segurança, aumentando os Domínios, sob qualquer pretexto de perigo e medo de Invasão, ou assistência que pode ser dada aos Invasores, envidam o quanto podem, para subjugar, ou debilitar seus vizinhos, por força ostensiva e artificios secretos, justamente por falta de outra Precaução, e por isso e em épocas futuras serão lembradas com honra." (1997: 93)

Essa afirmação de Hobbes do roubo, da espoliação e da força, da real Coletividade-Bando, como fazem Cidades e Reinos, contudo lembrada com honra qual nominal Coletividade-Estado, é similar à do ladrão nobre descrito por Hobsbawm, "aquele que corrige os erros [da nominal Coletividade-Estado e real ColetividadeBando], que dispensa a justiça e promove a eqüidade social (...) inunca mata, a não ser em legítima defesa (...)"' (1975: 37-38)

Hobbes e Hobsbawm postulam com tal asserção, que as formalidades comunicativas entre selvagens humanos partilha o mando com a força na politica, e que a força permanece como fundamento alternativo das formalidades comunicativas entre coletividades para a Teoria de Estado.

"Nos locais onde a força do Estado é remota, ineficiente e fraca, na verdade o governo sentir-se-á tentado a estabelecer boas relações com qualquer grupo forte local que não consiga derrotar. Se os ladrões dispuserem de força suficiente, terão de ser conciliados, como qualquer outro centro de força armada. Todos aqueles que viveram em épocas em que o banditismo se tornou descontrolado sabe que as autoridades locais têm de estabelecer um modus vivendi com os chefes dos ladrões, tal como todo cidadão de Nova Iorque sabe que a policia possui relações análogas com os bandidos urbanos" (Hobsbawm, 1975: 49-50).

Como se observa, a Teoria de Estado de Hobbes não distinguiu qualitativa e quantitativamente a Coletividade-Bando da Coletividade-Estado quanto ao uso da força, enquanto Hobsbawm distinguiu a intermitência entre elas. Nessas intermitências de superposição política por força a nominal Coletividade-Estado implica real Coletividade-Bando. Suas lideranças são politicamente trocáveis: bandido autorizado ou autoridade bandoleira? 
As "famílias maiores" referidas por Hobbes, honradas por força, designadas $\pi 0 \lambda ı \varsigma$ (cidades) para os gregos, passando por outras designações como 國 (kuo - nação), reinos, repúblicas, commonwealths, civitas, estados, têm em comum para os humanos a designação "pátria" como referente "[d] a defesa da comunidade pelo macho" em aliança ou coligação (Wrangham e Peterson, 1998: 283-284), reveladora da exclusão da fêmea, porquanto não designada "mátria", indiciando com isso também excluir o interesse feminino pela paz em favor do interesse masculino pela força nas Teorias de Estado.

"Entre os humanos e os chimpanzés, pelo menos, os grupos coligados de machos muitas vezes vão além da defesa (típica dos matriarcados dos macacos) para abranger a agressão não provocada, o que suscita a idéia de que nossos próprios conflitos intercomunitários poderiam ser menos terriveis se fossem conduzidos em favor dos interesses das mulheres em vez dos interesses dos homens. (...) Ent poucas palavras: o patriotismo gera a agressão" (Wrangham e Peterson, 1998: 285). O "marcador genético, detectável antes do nascimento, que prediz violência" é o cromossomo Y do macho. "Os indivíduos com esse genótipo" diz Carey, "são nove vezes propensos a serem presos e condenados por um ato de violência, relativanente a pessoas sem esses genes" as fêmeas. (Carey, 1994: 37) No Brasil, desconsiderando esta política por força, o desacato à política por mando implica 95,6\% de machos e 4,4\% de fêmeas da coletividade encarcerada (Justiça, 1996: 15).

Entretanto, é precisamente a incivilidade da "força" do macho, em detrimento da civilidade do "mando" da fêmea, a opção chimpanzé tomada para fundamentar persuasivamente as Teorias de Estado referidas, em que pese a frequiência dominante do mando nas superposições políticas, conforme os registros históricos e as taxas de uso da força, nos seus limites homicidas (itens 4 e 6 ).

\section{Política bonobo e política chimpanzé: intermitências}

A pré-civilidade dos humanos, por alternância do mando similar à política bonobo Si vis pacem, pacem age (Modesto, 1997-a) com a freqüência da força similar à política chimpanzé - Si vis pacem, para bellum -, reforçada pelas justificativas de "força" da parte macho da espécie na Sociologia, na Teoria Política, e no Direito pelas Teorias de Estado, só não partilha totalmente da incivilidade dos chimpanzés graças à dominância da política por mando freqüente entre as fêmeas, relativamente ao resíduo de força, de algumas etnias pacíficas. "Um levantamento mundial dos registros etnográficos de 50 grupos representativos, que não são países, revelou que quatro dessas sociedades os todas, os tikopias, os dorobos e os esquimós de Cobre não tiveram organizações militares regulares ou classes militares de qualquer espécie (...). Há ainda o caso dos semai senoi, um povo indígena de cerca de 13 mil pessoas que vive em comunidades de até 100 indivíduos, cultivando hortas e caçando para obter carne nas florestas tropicais úmidas da parte peninsular da Malásia" (Wrangham e Peterson, 1998: 105) 
Há também o registro de uma etnia polinésia designada moriori, com habitantes nas ilhas Chatham para eles Rekohu -, Nova Zelândia, descobertos no século X, cuja tradição implicava a política bonobo com "a recusa em lutar na guerra" O contacto com europeus veio por meio de caçadores de focas e baleias, que por lá criaram entreposto. No início do século XIX o contacto com a superposição política chimpanzé veio por invasão da etnia maori, também da Nova Zelândia. "Por se recusarem a lutar, os morioris acabaram sendo escravizados." A etnia moriori foi extinta em 1933. (Gurovitz, 1994: 6-10)

Parte dos humanos machos do Planeta Terra também participa da política bonobo, que tem no texto Tao, de Lao Tzy (-VI), a expressão do interpretante emocional da augeridade, o criador de similaridades pacíficas ou eutímicas, um dentre os três suportes da semiose, ou ação sígnica, na comunicação (Modesto, 1999).

Nesse texto Tao (por inédita reversão chinês-português de nossa autoria - Modesto, 1999), quando Lao Tzy descreve a ação política da Coletividade-Estado, mediante interpretante lógico involuntariamente cabente em uma "Teoria de Estado" as expressões de "força" são expressamente excluídas, qual política bonobo da real Coletividade-Estado. No texto Tao (uma cosmovisão acausal que se expressa mediante econômicos 5.321 similigramas registros indiciando similaridade entre a imagem e o objeto diagramado), a dominância da quale materna sobre a paterna no Planeta Terra ("céu inferior") implica todas as sintaxes de uma relação política segura e durável:

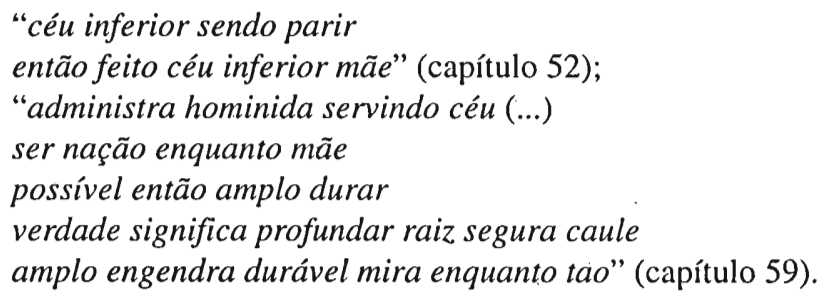

A primeira decorrência dessa quale materna implica administrar o espaço público mediante vago fazer - 無爲 wu wei e de forma similar ao espaço doméstico, por composição de interesses, dominando a exemplaridade ( $s h i h$ 式), com frequiência residual de modelos ( $f a$ 法) e ritos ( $l i$ 禮), composição que produz por contágio o retorno de um povo de conduta também compositiva:

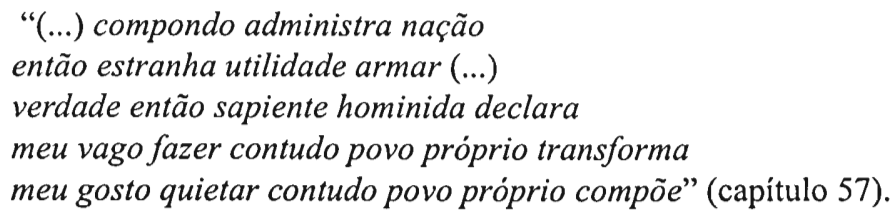

Administrar a nação por composição de interesses tem por conseqüência a inutilidade da "força" das armas e da pena de morte (homicidio torpe). O receio da 
morte não domina um povo, por conseqüência o homicídio torpe reverbera igualmente mortal para a própria intermitência da força dominante, pois amplia a matança no exemplo negativo do dominante:

\section{"povo amiüda porém sem recear morte suporta especular então matar acuaria enquanto disponha povo amiudado porém receando morrer (...) mede amiudar ser encarregando matar qual matar adulto (...) encarregado mata qual matar (...) medindo rareado ser sem lesada sua mão" (capitulo 74).}

As relações políticas ocidentais latinas e anglo-saxãs, em contraste com essas da etnia han, têm por fundamento um brocardo de Vegezio, "Si vis pacem, para bellum" - "Se queres a paz, prepara a guerra" (Fumagalli, 1981: 300) -, em realidade uma alogia, visto que paz e guerra não são similares mas antitéticos em relação ao querer, enquanto a relação política para Lao Tzy tem um fundamento diverso, material e formalmente lógico, com dados similares e complementares em relação ao querer, "Si vis pacem, pacem age" "Se queres a paz, faze a paz" (Modesto, 1997-a: 252).

Enquanto qualidade da ação política, o signo potência no ocidente tem freqüentemente a força por objeto, até os limites do homicídio e do genocídio próprio da politica chimpanzé, a potência no oriente tem freqüentemente o mando. por objeto, até o limite do wu wei próprio da politica bonobo.

Aquela alogia ocidental que fundamenta a politica chimpanzé tem por suporte sígnico na comunicação o interpretante energético da brutação (4 classe signica: Modesto, 1999; Peirce, 1978-2.257: 147) na expressão mítica do $B$ 'reshit, atribuído a Moisés (1985-1), outro dentre os três suportes da semiose na comunicação. Nesse texto encontramos o conhecido ciclo força e forra (força de um e forra do outro) da tradição hebraica de go 'el, o sanguífico deus 'El "vingador de sangue" (Moisés, 1985-1.9,5-6: 42-43; Jerusalém, 1985-n.d; n.h: 43, 272), expresso no mando “'Quem matar Caim será vingado sete vezes"' (Moisés, 1985-1.4,15: 37), cuja manifestação moderna está em execução por judeus no genocídio de palestinos em territórios ocupados destes desde 1967.

O ciclo da força, por domestiação mítica hebraica, tem a matança fratricida como ação de investidura no mando, vinda por logos fático - verbo executor - de Moisés (-XIII), presumido fundador da religião judaica e condutor do povo hebreu do Egito para a "terra prometida" Essa matança fratricida é a ação de investidura da tribo levita para o serviço sacerdotal do sanguífico preponente $Y h w h$, preparando o povo, desde Abraão (caldeu que teria nascido entre -XX e XV em Ur), para a conquista genocida da terra de Canaã.

"Moisés viu que o povo estava desenfreado, porque Aarão os havia abandonado à vergonha no meio dos seus inimigos. Moisés ficou de pé no meio do acampamento e exclamou: 'Quem for de Iahweh venha até mim!'Todos os filhos [da 
tribo] de Levi reuniram-se em torno dele. Ele lhes disse: 'Assim fala Iahweh, o Deus de Israel: Cinja, cada um de vós, a espada sobre o lado, passai e tornai a passar pelo acampamento, de porta em porta, e mate, cada qual, a seu irmão, a seu amigo, a seu parente.

Os filhos de Levi fizeram segundo a palavra de Moisés, e naquele dia morreram do povo uns três mil homens. Moisés então disse: 'Hoje recebestes a investidura para Iahweh, cada qual contra o seu filho e o seu irmão, para que ele vos conceda hoje a bênção"' (Moisés, 1985-2.32,25-29: 154-155).

Como lembra Miles, o "que contava a favor dos levitas para Moisés não era o fato de terem identificado os lideres da idolatria, mas precisamente o fato de estarem dispostos a matar 'irmãos, vizinhos e parentes' Isso se parece muito com as demonstrações de violência dos membros de uma gangue, que provam assim sua capacidade de matar e a disposição de colocar a lealdade ao chefe acima de todos os outros valores (...) precisamente, matar a familia para provar sua lealdade" (1997: 143).

Na lógica da politica bonobo de Lao Tzy, a expressão armada da "força" tem por decorrência a ausência de vencedores - o homicídio torpe re-produz homicidio; enquanto a robustez armada implica a inferioridade daquela prisão cíclica da força e forra com as mortes, a maleabilidade e a debilidade implicam a superioridade da paz desarmada com a vida:

$$
\begin{aligned}
& \text { "verdade então arma robusta medida sem vencedor (...) } \\
& \text { conquanto robustez grandeza residem inferior } \\
& \text { maleável débil residem superior" (capitulo 76). }
\end{aligned}
$$

O sumo dessa superioridade desarmada que produz vida tem suporte lógico na paradoxal ação política sem lutar - 不爭 pu cheng - cuja imagem é a da água, que afia hominidas sem produzir coxos de guerra:

\author{
"superior bom conforme água \\ água boa afiando inúmeras coisas contudo sem luta \\ reside multidão hominida enquanto lugar maldado \\ conquanto indiciando por tao (...) \\ adulto reflete sem lutar \\ conquanto vagando coxeio" (capítulo 8).
}

Para que não desprezemos a indução cultural implicada na expectativa mnemônica que tal domestiação, territorial e extraterritorial, representa (Kaltenmark, 2000: 13 e 9), a etnia han, a mais populosa do mundo, compõe aproximadamente um quarto do mercado mundial. Ocupando hoje 9 milhões e $597 \mathrm{mil} \mathrm{km}^{2}$, há aproximados 1 milhão e duzentos mil chineses, 95\% da etnia han (1.140.000), e minorias como mongóis, manchus, tibetanas na periferia geográfica. (Larousse, 1995-6: 1361-1362) 
Esta quarta parte da população mundial, nas suas superposições políticas, é condicionada desde o século -VI pela cosmovisão acausal expressa em Tao de Lao Tzy (ver Maspero, 2000: 20, 38-49, 89), diluída por um corpus de doutrinas que vão do mitológico à mística pessoal, corpus que a reflexão ocidental freqüentemente confunde com filosofia, ou sistematicamente busca converter em teologia, desde as tentativas de colonização religiosa perpetradas pela Companhia de Jesus, a partir dos jesuítas portugueses Francisco Xavier, em 155़2, e Melchior Nunez Barreto, em 1555, e do florentino Matteo Ricci, em 1601 (Lécrivain, 1991: 42, 55-57). São aproximadamente 1.120 volumes e 1.476 títulos de obras (Kaltenmark, 2000: 11), além de mais de uma centena de traduções, só em inglês (Pine, 1996: XXI), deste texto de Lao Tzy, o mais conhecido e influente da cultura han no ocidente (Wing-Tsit, 1973: 137), mas que pende de abordagem atenta pelas disciplinas Sociologia, Teoria Política, e Direito.

É em função de tais dados da política bonobo, a política por mando entre os han, que se pode verificar a parcialidade com que se justifica e generaliza a intermitente superposição política por "força" das nominais Coletividades-Estado sobre as demais coletividades nos respectivos territórios de dominação, retirando da Sociologia, da Teoria Política, e do Direito, como se observa também por falta de universalidade da hipótese comum européia, o status de ciência sensu stricto, enquanto partilham da baixa seletividade do conhecimento comum, em que prepondera o macho avezado à "força" justificada por tais disciplinas.

A característica da pré-civilidade humana, por sua freqüência de política chimpanzé, portanto, pode ser resumida pela freqüência (e não-resíduo) da política por "força", justificada por sobreditas disciplinas reivindicando o monopólio da "förça" própria da incivilidade dos chimpanzés, e representativa apenas do marcador genético da parcela macho da espécie humana, alternada à superposição política por mando, similar à civilidade bonobo, e à comunhão eutímica culturalmente expressa naquele texto Tao. Na incivilidade chimpanzé, conforme observamos descrito e resumindo, domina a superposição política por força, relativamente ao mando freqüente (Wrangham e Peterson, 1998: passim, 159-161, 178-182).

Aplicando exemplificadamente o modelo de civilidade da Hominilogia na ação política das coletividades humanas, notaremos uma política bonobo no caso da ação de chineses ao devolver - sem uso da força (wu wei - vago fazer) - um avião de espionagem EP-3E com 24 militares da Coletividade-Bando estadunidense que invadiu o espaço territorial da China, implicando no homicídio do piloto chinês que comandava um caça F-8 no próprio território, em 01/04/01, suportando a lesão em troca da expressão very sorry do bando agressor liderado pelo "rogue preposed president" George Walker Bush (Salgado, 2001: 56), considerado por britânicos em pesquisa o terceiro humano mais perigoso do mundo, superado apenas pelos promovidos Saddam Hussein, do Iraque, e Osama Bin Laden, árabe da organização bélica Al Qaeda (Tarde, 2002: 11 A).

O complementar oposto da política bonobo, justificada por sua Teoria de Estado, podemos descrever na política chimpanzé daquela coletividade da etnia judaica que, mediante a técnica do holocausto - abstração retórica da própria vontade 
em nome da presumida vontade homicida de um sanguílico deus macho, 'El, de Isra'El (uma teofederação - ver Modesto, 1999) -, técnica também designada Nazi-Jewish ou "Judeu-Nazi" pelos judeus Yeoshua Leibowitch e Israel Shahak (Said, 1997: 11), caracteriza "os métodos usados pelos Israelitas para submeter e reprimir os Palestinos" (Shahak, 1997: 24-25), usurpa terras que arbitra serem dadas num passado mítico e em corpo presente por esse deus go'el, vingador do sangue de Isra'El, e faz a limpeza étnica dos habitantes locais, com a cumplicidade das resoluções contrárias e inaplicadas da Coletividade-Bando ONU.

Para a conquista dessas terras, a Coletividade-Bando Israel, "Nazisrael". conforme designa José Arbex Junior (2002-a: 17), tem por fundamento totalitário de sua Teoria de Estado (Shahak, 1997: 37-39) o "conceito [machista-racista] de Israel como 'um estado Judeu', como Israel se define formalmente (...) [por] Lei Constitucional (...) aprovada por uma enorme maioria do Knesset. Por esta lei, a nenhum partido, cujo programa se oponha àbertamente ao principio de 'um estado Judaico' ou proponha alterá-lo por meios democráticos, é permitido participar nas eleições para o Knesset"

Este "exemplo mostra que o Estado de Israel não é uma democracia devido à aplicação de uma ideologia Judaica dirigida contra todos os não-Judeus e aqueles Judeus que se opõem a esta ideologia. (...) Os cidadãos de Israel não-Judeus não têm o direito de igualdade perante a lei. Esta discriminação é expressa em muitas leis Israelitas" (Shahak, 1997: 16-17, 20).

Esse fundamento racista, totalitário e hitleróide da Teoria de Estado referida vem sendo implementado pelo genocida "Ariel Sharon [que] propôs formalmente na Convenção do Likud que Israel devia adotar o conceito das fronteiras Bíblicas como política oficial" (Shahak, 1997: 25). Para tanto, a política chimpanzé da Coletividade-Bando Israel promove a matança por homicídio bélico de palestinos desde 1967, quando ocupou suas terras na Faixa de Gaza, na Cisjordânia, e na Jerusalém Oriental, partilhadas pela ONU em 1947, (Abril, 2003), recrudescendo a matança em 29/03/02, quando, desde o início da segunda intifada ou levante contra a ocupação da Coletividade-Bando Israel, em 28 de setembro de 2000, até 29/09/02, 41 mil palestinos e 3 mil judeus foram feridos (Paulo, 2002-a: A 18), enquanto o parcial escore homicida já está em 2,702 palestinos por 1 judeu mortos, por números do mercado político, ganho de 1.908 resistentes palestinos mortos em terras ocupadas, ao custo de 706 mortes judaicas invasoras, não incluídos os judeus mortos por judeus "por engano" até 14/03/ 03 (Paulo, 2003-e: A9; Paulo, 2003-f: A12), e sem contar a destruição dos espaços públicos da Coletividade-Estado Palestina, e da destruição punitiva das moradias dos familiares dos resistentes mortos, além de imóveis de acesso.

Esse arcaísmo tribal de pena coletiva, similar ao padrão homicida do deus Yhwh nas míticas Sodoma e Gomorra, vem pelo mando homicida do sequaz de Adolf Hitler, Ariel Sharon, e discípulos da Coletividade-Bando Israel com o quarto exército do mundo (Arbex Junior, 2002-b: 13, 93), militar e fïnanceiramente cevados no mercado chimpanzé pelo estadunidense George Walker Bush. 
Relevante lembrar. Esta segunda intifada, designada Al Aqsa, foi programadamente iniciada pela oposição de Ariel Sharon do partido Likud que, buscando desestabilizar o preposto pelo partido trabalhista Ehud Barak da nominal Coletividade-Estado Israel, "visitou” em 2000 por provocação o Santuário Nobre (Haram al Sharif), local mais sagrado de Jerusalém para palestinos e judeus, por estes designado Monte do Templo, implicando repulsa palestina imediata, que se disseminou pela cidade e territórios ocupados. (Paulo, 2002-b: A 18) Valeu-se da revolta palestina que insuflou para titular-se como o primeiro-ministro judeu que poderia desinflar o movimento mediante a política do genocídio. Sharon implementou a insegurança e morte de 601 e ferimento de $3 \mathrm{mil}$ da própria etnia para benefício pessoal.

A domestiação (ver item 2) que suporta o moiseísmo expresso pela nominal Coletividade-Estado EUA, com a real Coletividade-Bando de Bush, é a mesma da Coletividade-Bando de Ariel Sharon, a Torah ("Instrução") hebraica, dominada pela brutação (ver item 1) de Yhwh e seu profeta Moisés, com o mando e força homicidạs (Modesto, 1999). Seu derivado recente é o fundamentalismo protestante de espécie metodista de Bush (Aith, 2003: A23; Vulliamy, 2003: 13, 15, 16), variante sectária do anglicanismo, a teologia oficial da Inglaterra fundada pelo uxoricida contumaz Henrique VIII (1.491-1.547).

O hitleróide Bush, número um no mercado do colt, assertivo alcoólatra no espaço público (Vulliamy, 2003: 14), reticente da cocaína no espaço doméstico (Arantes, 2003: E4), apresenta folha corrida alentada. Trânsfuga da guerra do Vietnã (virtude paradoxal), sádico, empresário corrupto e vezeiro na fraude, tráfico de influência (Vulliamy, 2003: 14), graças a isso foi governador do Texas (1995-1998; 1999-2000), fracassou no voto popular para a presidência da República (2001-2004) com seus 49.819.600 votos (Tarde, 2003: 3A; Parkinson, Lamourie, 2003), perdendo para Al Gore (50.156.783), contudo pôde comprar mediante fraude, auxiliado pelo consanguíneo Jeb Bush governador na Flórida, o status de preposto da nominal Coletividade-Estado EUA.

Bush serviu-se da velha Teoria de Estado chimpanzé e dos coadjuvantes da Suprema Corte, que suspenderam a recontagem dos votos na Flórida para coonestar a malta (Paulo, 2001: A2), e toma como precedente (normóide simulando a espécie histórica anglo-saxã de mando-casual) de sua estratégia autocrata o modelo terrorista de Ronald Wilson Reagan (1981 a 1988).

Reagan, de 1982 a 1986, por meio do Departamento de Estado e da Central Intelligence Agency (CIA), financiou o terror dos guerrilheiros "Contra" instrumentos de sua Coletividade-Bando, buscando sabotar a Revolução Sandinista dominante na Nicarágua com Daniel Ortega. O terror de Reagan foi condenado pela Corte Internacional de Justiça da ONU, designando tal brutação no dialeto legista como "uso ilegítimo da força" (Chomsky, 2002: 11). A Coletividade-Bando EUA desacatou o julgamento, anunciando não mais aceitar a competência da Corte Internacional de Justiça. Com isso, essa nominal Coletividade-Estado denota e assume conduta de Coletividade-Bando, nos termos da Carta das Nações Unidas (ONU) de 1945, art. 94, $1^{\text {"e }} 2^{\text {a alíneas. }}$ 
Se colocarmos em sintaxe lógica o terrorismo de Reagan com "A Estratégia de Segurança Nacional dos Estados Unidos de América" do Norte (America, 2002-V: 13-14), essa nominal Coletividade-Estado subsome-se como uma "rogue state and terrorist collectivity" pelos atributos 4 (patrocinar terrorismo) e 2 (desacatar leis internacionais e violar tratados em que são parte). "Os Estados Unidos (...) são hoje a única nação que, ao mesmo tempo, foi condenada por praticar terrorismo internacional pela Corte Mundial e vetou uma resolução do Conselho de Segurança convocando os Estados a respeitarem o direito internacional" (Chomsky, 2002: 12).

É com essa credencial de Coletividade-Bando e Estratégia de Insegurança Nacional e Internacional de 2002 que George Walker Bush fomenta no geral o mercado interno estadunidense. A utilidade gerencial de Bush como preposto da real ColetividadeBando EUA está em servir aos interesses corporativos da indústria da tecnologia de armas, testando suas inovações de destruição em massa, e escoando sua produção pelo fomento de novos conflitos no planeta, e aos interesses energéticos de acesso ao petróleo no Oriente Médio, seus financiadores eleitorais (Vulliamy, 2003: 12-15), aliados do sionismo da costa leste do território norte-americano (Vulliamy, 2003: 16), que "vê na recriação do Estado judeu um sinal divino de que a volta do Messias está próxima" (Gryzinski, 2003: 44).

O reflexo administrativo dessa geopolítica industrial e comercial é a instrumentalização da nominal Coletividade-Estado Israel (Arbex Junior, 2002-b: 18), enclave e sucursal estadunidense numa região dominada por autocracias árabes fundadas no petróleo. Ariel Sharon é a longa manus dessa Coletividade-Bando EUA na região, além de outras associadas do bando pelo mercado mundial, caso do "poodle da Casa Branca", o primeiro-ministro inglês Tony Blair (Sabino, 2003: 71). A expressão desse conflito comercial justapõe de um lado protestantismo e judaísmo e de outro islamismo, todos capazes de cortar a jugular do próprio filho, como Abraão com Isaac.

Seguindo essa tradição, George Walker Bush, com 155 homicídios torpes no currículo, é o maior homicida na história dos governadores das unidades federadas estadunidenses. Homicídio torpe é aquele homicídio sistemático justificado por expressa função jurisdicional e dissimulada função hierática (sagrada ou messiânica, conforme acima) da toga, mediante agentes da Coletividade-Bando, travestidos de ColetividadeEstado. (Modesto, 1999) Na história recente das matanças no território estadunidense, Bush só é superado em números por Timothy James McVeigh, que mediante 2 mil quilos de explosivo detonados na garagem do prédio do governo federal da cidade de Oklahoma, matou 168 pessoas em 1995. (Parkinson, Lamourie, 2003)

Com esse currículo, o autocrata Bush foi beneficiado pela fortuna de gerenciar o ódio responsivo dos excluídos e lesados do planeta e das vítimas próximos e remotos do petróleo, como palestinos da segunda Intifada ou levante contra a ocupação ḍa Coletividade-Bando Israel na Faixa de Gaza, Cisjordânia e Jerusalém Oriental (20002002) - a primeira foi de 1987 a 1991 (Veja, 2002-1.747: 49) -, além de árabes, afeganes, ..., contaminados pela memória histórica de índios, mexicanos, cubanos, panamenhos, nicaragüenses, chineses, coreanos, vietnamitas, ..., que retaliaram em 11 de setembro 
de 2001 aqueles 168 anos de homicídios e matanças de estadunidenses em 228 anos de independência (ver fïg. 3).

Essa retaliação, cuja autoria intelectual não foi comprovada, ainda que se tenha um culpado de plantão, Osama Bin Laden, teve por leatros o World Trade Center em Nova York e índice do mando excludente (2.948 mortos), a Secretaria da Defesa e do Estado-Maior das Forças Armadas dos Estados Unidos da América do Norte (Pentágono) em Washington (184 mortos) e índice de força da política chimpanzé, e o avião abatido na Pensilvânia (quarenta mortos), totalizando 3.191 mortos, incluindo os quinze árabes dentre os dezenove seqüestradores (Times, 2002: H2), exibiu de modo convincente que respectivos $77 \%$ e $78 \%$ dos séculos XIX e XX investidos em homicídios e matanças por estadunidenses pelo mundo qualificaram de onipresente o ódio dos lesados, sem implicar onipotência para aquela Coletividade-Bando, a despeito da sua vantagem tecnológica e bélica.

Sem lastro de mando crível nas eleições de preposto da nominal Coletividade-Estado EUA em 2000, fracassado nessa crença na onipotência da tecnologia bélica, como indiciado e reiterado depois de 11.09.01, e fracassado no suborno pelos quais teria em mãos o suspeito Osama Bin Laden (US\$25 milhões por informações que levem à captura Paulo, 2003-b: A 12), depois da invasão do Afeganistão em 2001 e do golpe de Estado imposto à esta nominal Coletividade-Estado - a Coletividade-Bando dos talebans -, produzindo entre 3,1 mil e 3,6 mil mortos (Sandoval, 2003: A19), Bush amalgamou aqueles interesses industriais, comerciais e energéticos ao ódio pessoal (Paulo, 2003-g: A2) e emulação vingativa com a suposta tentativa de Saddam Hussein de assassinar o pai George Herbert Walker Bush, quando em visita ao Kwait em 1993 (Paulo, 2003-h: Al1), para empreender razia a este seu congênere autocrata e ex-aliado.

Para tanto, Bush reiterou durante meses a tradição de cooptar as Coletividades-Estado partícipes do Conselho de Segurança da ONU para dar credibilidade a seu mando genocida por intermédio de resolução desse conselho. Utilizou-se de seu arsenal Far West (bando). Mentiras e provas falsas (imputar ao Iraque parelha com a Coletividade-Bando EUA na posse de armas biológicas, nucleares ou químicas; vincular os inimigos políticos Saddam Hussein a Osama Bin Laden Anderson, 2003: A 18), blefes, compra de votos ("a diplomacia do dólar" [Entous, 2003: A9], "prática comum" na ONU Holsti, 2003: A 12), chantagem bélica a Coletividade-Estado caso vete resolução ditada por Bush (Press, 2003: A 12), suborno (o vice-presidente Dick Cheney -, Reuters, 2003: A 16), escuta clandestina ...

A base dos dados demonstrativos da intermitente superposição política estadunidense implicando Coletividade-Bando pode ser ampliada, basta acessar a internet buscando pelos índices do Far West: "mentira" ... "suborno" ... queimas de arquivo, associados às alcunhas de integrantes e escravos do staff de Bush, como Donald Rumsfeld e seus comparsas, o iraquiano Saddam Hussein (1979-2003) e o coreano Kim Jong II (1994-) (Canzian, 2003-b: A I6). A diferença entre Fernandinho Beira- 
Mar (Luiz Fernando da Costa) gerente de um bando em território brasileiro e o estadunidense George Walker Bush é uma questão de escala.

A intermitência dessas tentativas de mando crível e dissimuladas vilezas por Bush, desmascaradas em tempo real e reproduzidas urbi et orbi pelo rádio, pela televisão, pelos jornais, pela internet, implicaram reflexão madura da ColetividadeFamília que, reciclando o aprendizado das estratégias gandhianas e lennonianas do século passado em face das mesmas Coletividades-Bando e suas intermitências políticas, exprimiu-se mediante ações próprias da política bonobo.

Na primeira metade do século XIX, a estratégia gandhiana (Mahatma Gandhi, 1869-1948) de desacato à dominação inglesa na Índia implicou no espaço público o mando político (assimétrico) da Satyagraha (verdade tenaz) mediante ahimsa (não-violência), espécie no gênero wu wei (itens 4 e 6).

Na segunda metade do século, a estratégia lennoniana (John Ono Lennon, 1940-1980 - Modesto, 1999) desacata a dominação estadunidense no Vietnã, criando e induzindo expectativas pacíficas por meio da música e dos alter-mentes (medicamento $\cong$ alimento $\cong$ "droga" Modesto, 1994, 1999), expandindo o espaço doméstico e o mando eutímico (simétrico) para o espaço público, rompendo fronteiras e limites com o suporte do próprio corpo no uso de camisetas estampando mensagens contra a guerra, badges, passeatas, festivais, performances, subvertendo até a propaganda dos outdoors para "vender" a paz.

Ambas estratégias, a de Gandhi e a de John Lennon, incidiram sobre dominação ou genocídio já em curso (ingleses na Índia de 1772 a 1947, estadunidenses no Vietnã de 1955 a 1975), com respectivas velocidades e alcances tecnológicos nas escalas do rádio e da televisão.

O repertório das estratégias de Gandhi e Lennon, partilhado pela expectativa mnemônica dos humanos nesse século XXI, foi acelerado para a velocidade e o alcance tecnológicos na escala da internet.

Incorporando tanto a potência do mando eutímico quanto do mando político, a liberdade acausal da Coletividade-Família mundial no espaço doméstico exprimiu no espaço público a política bonobo desqualificadora da Coletividade-Bando estadunidense, antecipando condenação e desacato às justificativas de uma invasão territorial vindoura por mentira e fraude dos acólitos de Bush para a suposta "posse de armas de destruição em massa" pelo Iraque (o slogan para o ciclo da destruição e para o empreendimento de reconstrução do Iraque pela famiglia Bush), mediante o ódio performático de repúdio ao genocídio por vir, com recordes de ações pacifistas e o maior protesto da história mundial por praças e passeatas na América, África, Europa, Ásia, e Oceania.

O circo das Coletividades-Bando travestidas de nominais ColetividadesEstado, a cada época no respectivo padrão midiático dominante, pode gerar a ilusão de alta freqüência da força pela mobilização da atenção, reduzindo a percepção de mundo à singularidade referida aos ambientes de conflito. Sem distância crítica, essa distorção é reproduzida como "verdade" nas Teorias de Estado chimpanzé. 
Os complementares opostos Coletividade-Bando estadunidense de um lado e o surto pacifista mundial de outro, adiante quantificados respectivamente os homicídios bélicos estadunidenses e os desazos bélicos (não-implicação homicida) no espaço público pela Coletividade-Família mundial, demonstram que a força não é dominante o suficiente para fundamentar qualitativamente uma Coletividade-Estado, também pelo grau de repulsa que gera, ainda que o padrão midiático deixe de registrar o fato, como na primeira metade do século XIX.

A alta freqüência de manifestações pacifistas nos dias 15 de fevereiro e 15 de março de 2003, sem contar as manifestações diárias durante o genocídio, implicaram circunstância tecnicamente feliz para falsificar a asserção de "dominância da força", pondo à vista e aos olhos a expressividade da desqualificação do homicídio pelas lentes do padrão midiático que, sem ele, ficaria oculta.

Pôde-se observar essa quantificação da Coletividade-Família no teatro planetário de 15.02.03 mediante estimativas conservadoras (da Polícia): Rio de Janeiro (3 mil), São Paulo (8 mil), Buenos Aires (10 mil), Santiago (3 mil), Assunção (400), Nova York (250 mil), Ottawa (milhares), Quebec (milhares), Cidade do Cabo (5 mil), Londres (750 mil), Madri (660 mil), Barcelona (1,3 milhão), Paris (250 mil), Bruxelas (50 mil), Amsterdã (70 mil), Roma (1 milhão), Oslo (60 mil), Berlim (600 mil), Atenas (150 mil), Tel Aviv (2 mil palestinos e israelenses lado a lado), Damasco (200 mil), Bagdá (dezenas de milhares), Bangcoc (2 mil), Tóquio (5 mil), Auckland (5 mil) ...

No Brasil, o preposto da Coletividade-Estado Luiz Inácio Lula da Silva apoiou oficialmente os atos pela paz, com incentivo de participação para os integrantes de primeiro escalão do governo; além do Rio de Janeiro e de São Paulo, houve manifestações em Manaus (AM), Fortaleza (CE), Recife (PE), Salvador (BA), Brasília e Goiânia (GO), Belo Horizonte (MG), Vitória (ES), Sorocaba (SP), Curitiba e Foz do Iguaçu (PR), Florianópolis e Chapecó (SC), Porto Alegre (RS) ... (Paulo, 2003-d: A 16 e A 17)

"Milhões de manifestantes foram às ruas ontem [15/02/03] em cerca de 60 países - mais de 600 cidades - para protestar contra uma ação militar no Iraque e para pedir paz, numa mobilização global inédita contra uma guerra que ainda não começou. (...) [A] estimativa mais conservadora coloca o total [de participantes] em ao menos 5 milhões de pessoas" (Paulo, 2003-c: A15).

Reiterando aquele protesto de 15 de fevereiro em 15 de março, pôde-se observar indiciada mais uma vez a Coletividade-Família como descrita nas correlações fenomenológicas do item 1. "Os pacifistas não têm líderes nem chefes. Eles formam na Europa e nos Estados Unidos uma rede difusa e horizontal de entidades. Um último levantamento indica que o território norte-americano está empipocado por 249 agrupamentos regionais (...) ninguém é dono do movimento (...). Esse ecumenismo é permitido pelo fato de inexistir entre os pacifistas uma única orientação ideológica, com guardiões de ortodoxias e disputas de espaço com dissidentes.

Há de tudo. Como empresários que deram dinheiro para a campanha eleitoral de George W[alker] Bush, marxistas belgas, luteranos alemães, bispos 
italianos, estudantes muçulmanos na Holanda (...). A internet não permitiu só baixar os custos de mobilização (...) que seria caríssimo se dependesse do correio. Permitiu também diluir os centros de poder. (...) Cada militante escolhe o seu cartaz, faz o download pela internet e ainda imprime, para levar no bolso, os panfletos que irá distribuir. O salto qualitativo não é apenas tecnológico. É também de qualidade política" (Natali, 2003: A20)

Contudo, empregando $30 \%$ do PIB em gastos militares (Canzian, 2003a: A20), com o apoio em tempo real de $78 \%$ dos estadunidenses, George Walker Bush promove o genocídio iraquiano (Paulo, 2003-j: A 16), indiciando e dando expressão à Coletividade-Bando estadunidense no mercado mundial, com seu grau e medida de lesividade e terror: são 1.254 mortos civis e 5.112 feridos (Sandoval, 2003: A 19), ao custo de 145 estadunidenses mortos de 20 de março, início da invasão, até 9 de maio (Paulo, 2003-k: A 16).

Dentre as armas de destruição em massa, foi utilizada uma "descarga de quase 300 toneladas de projéteis de urânio empobrecido [ou enfraquecido] pelos tanques anglo-americanos [no Iraque]" (Angelo, 2003: A I 1). "Recente visita dos observadores [da ONU] ao Iraque constatou inúmeros casos de câncer e de deformações genéticas causados pela bomba de urânio enfraquecido" (Almeida, 2003: A2). São os resquícios da invasão da Coletividade-Bando estadunidense em 1991. "Os casos de câncer [em Basra] teriam aumentado muito nos anos 90 - cerca de 150\%. Os iraquianos culpam a munição com urânio que teria sido usado pelos norte-americanos na Guerra do Golfo pelo problema" (Paulo, 2003-i: A15).

Na pré-civilidade dos humanos; freqüentes a política por força, como vimos nesse início de milênio com Bush e Sharon, e a política por mando, como vimos com a Coletividade-Família mundial, com dominância do mando relativamente à força, como se observou quantificado nos casos históricos documentados, em que pese o êxtase homicida da Coletividade-Bando estadunidense visto no item 4, e sem que esta força se tenha reduzido ao residual como entre os bonobos, e, contudo, é aquela freqüência não dominante da "força" que fundamenta as disciplinas Sociologia, Teoria Política, e Direito, sem qualquer amparo demonstrativo de generalidade e universalidade na história humana.

Como se observa, a Teoria do Estado encontra respaldo justificador da "força" nas sobreditas disciplinas, partindo da superestimação da força na política, o objeto reduzido à política por "força" Sem a re-composição desse objeto pela Hominilogia e para incluir a política por mando, oculta-se a superposição política por mando eutímico da parcela fêmea dos humanos e a superposição política por mando político da Coletividade-Família com a política bonobo, padrão de civilidade para fêmeas e machos humanos já previsto por Lao Tzy em sua involuntária "Teoria de Estado" há 2,6 mil anos.

São Paulo, agosto de 2002. (Atualizado pelo autor em maio de 2003) 
Referência Bibliográfica

ABRIL, Almanaque (2003). CD-ROM. Mundo. Países. Em Almanaque Abril: São Paulo: Editora Abril.

AITH, Márcio (2003). Bush coloca religião no centro da vida política. Em Folha de S. Paulo. Mundo. P. A23. 23/02/03. São Paulo: Empresa Folha da Manhã.

AKOUN, André et alii (1983). Dicionário de Antropologia. Traduzido por Germiniano Cascais Franco. Lisboa: Editorial Verbo.

ALMEIDA, Luciano Mendes de (2003). Justiça e Paz. Em Folha de S. Paulo. Opinião. P. A2. 22/02/03. São Paulo: Empresa Folha da Manhã.

AMERICA, United States of [North] (2002). The National Security Strategy of the United States of [North] America. September 2002. George Walker Bush. 25/09/ 02. Washington: <http://www.whitehouse.gov/nsc/nss.pdf>.

ANDERSON, Lisa (2003). 'EUA não conseguirão regime confiável'. Entrevista. Em Folha de S. Paulo. Mundo. P. A18. 18/03/03. São Paulo: Empresa Folha da Manhã.

ANGELO, Cláudio (2003). Ambiente sofreu muito mais sob Saddam. Em Folha de S. Paulo. Ciência. P. A11. 05/05/03. São Paulo: Empresa Folha da Manhã.

ANÔNIMO AKKAD (1994). Enuma elish - poema babilónico de la creación. Edición y traducción del acadio dialetal por Federico Lara Peinado. Colección Paradigmas. Biblioteca de Ciencias de las Religiones. P. 45-89. Madrid: Editorial Trotta.

ARANTES, Silvana (2003). Antiamericanismo se faz presente no evento. Em Folha de S. Paulo. Ilustrada. P. E4. 12/03/03. São Paulo: Empresa Folha da Manhã.

ARBEX JÚNIOR, José (2002-a). Nazisrael. Em Caros Amigos. № 61. Abril de 2002. P. 17. São Paulo: Editora Casa Amarela.

ARBEX JÚNIOR, José (2002-b). Terror e esperança na palestina. Série história imediata. São Paulo: Editora Casa Amarela.

ARIĖS, Philippe (1981). História social da criança e da familia. Traduzido por Dora Flaksman. Rio de Janeiro: Editora Guanabara Koogan.

ARISTÓTELES (1998). Politica. Edição bilingue. Traduzido do grego por António Campelo Amaral e Carlos de Carvalho Gomes. Coleç̧ão: Vega Universidade / Ciências Sociais e Políticas. Lisboa: Vega.

BOHR, Niels (1995). Física atômica e conhecimento humano ensaios $1932-$ 1957. Traduzido por Vera Ribeiro. Revisão técnica pelo físico Ildeu de Castro Moreira, do Instituto de Física da UFRJ. Rio de Janeiro: Contraponto.

BONALUME NETO, Ricardo (1991). Lógica intervencionista domina história dos EUA. Em Folha de S. Paulo. Guerra. P. 6-Especial. 03/02/91. São Paulo: Empresa Folha da Manhã.

CANZIAN, Fernando (2003-a). Bush parte agora para ataque na frente doméstica. Em Folha de S. Paulo. Mundo. P. A20. 20/04/03. São Paulo: Empresa Folha da Manhã. 
CANZIAN, Fernando (2003-b). Empresa ligada a Rumsfeld ajudou a Coréia. Em Folha de S. Paulo. Mundo. P. A16. 10/05/03. São Paulo: Empresa Folha da Manhã.

CAREY, Gregory (1994). Interview to Philip Elmer-Dewitt. The genetic revolution. In Time. P. 30-37. 17/01/94. New York: Time.

CHOMSKY, Noam (2002). A nova guerra contra o terror. Em Estudos avançados Universidade de São Paulo. V. 16, no 44. Janeiro/Abril de 2002. P. 5-33. São Paulo: Instituto de Estudos Avançados da Universidade de São Paulo.

DAVID, René (1996). Os grandes sistemas do direito contemporâneo. Traduzido por Hermínio A. Carvalho. São Paulo: Martins Fontes.

ENTOUS, Adam (2003). Dólares podem conquistar votos. Em Folha de S. Paulo. Mundo. P. A9. 10/03/03. São Paulo: Empresa Folha da Manhã.

FOUTS, Roger; MILLS, Stephen Tukel (1998). O parente mais próximo: o que os chimpanzés me ensinaram sobre quem somos. Traduzido por M. H. C. Côrtes. Rio de Janeiro: Objetiva.

FOX, Robin Lane (1993). Biblia: verdade e ficção. Traduzido por Sergio Flaksman. São Paulo: Companhia das Letras.

FUMAGALLI, Giuseppe (1981). L'ape latina. P. 300. Item 2.582. Milão: Editore Ulrico Hoepli Milano.

FUND, United Nations International Children's Emergency (2002). Impact of armed conflict on children. 22/08/02. <http://www.unicef.org/graca/patter-ns.htm>.

GARMUS, Ludovico (1992). Pentateuco e Notas Explicativas. Em A Biblia. Traduzido diretamente dos originais hebraico, aramaico e grego, com recorrência à Bíblia Hebraica de Stuttgart e à edição crítica de Goettingen. P. 25-234. Petrópolis: Vozes.

GILISSEN, John (1995). Introdução histórica ao direito. Traduzido do francês por A. M. Hespanha e L. M. Macaísta Malheiros. Lisboa: Fundação Calouste Gulbenkian.

GRYZINSKI, Vilma (2003). Quem é o inimigo. Em Veja. Especial. Edição 1791. P. 42-44. 26/02/2003. São Paulo: Editora Abril.

GUROVITZ, Helio (1994). Povo moriori habitou ilhas [Chatham, Nova Zelândia]. Em Folha de S. Paulo. Ciência. P. 6-10. 25/12/94. São Paulo: Empresa Folha da Manhã.

HEISENBERG, Werner (1989). Physics and Philosophy. Introduction by Paul Davies. London: Penguin.

HESÍODO (1991). Teogonia: a origem dos deuses. Edição bilíngüe gregoportuguês. Traduzido do grego por Jaa Torrano. P. 103-163. São Paulo: Iluminuras.

HOBBES, Thomas Hobbes of Malmesbury (1997). Leviathan, or the matter, forme, \& power of a common-wealth ecclesiasticall and civill. Authoritative text with Backgrounds and Interpretations of Pierre Bayle, Thomas Hobbes, Robert Filmer, 
James Harrington, Bishop Bramhall, Edward Hyde, Gottfried Wilhelm Leibniz, CharlesLouis de Secondat (Montesquieu), Henry Sidgwick, Michael Oakeshott, Leo Strauss, Johann P. Sommerville, Richard Tuck, Jean Hampton, David Johnston, George Kateb, Richard E. Flathman. A Norton Critical Edition in the History of Ideas by Richard E. Flathman and David Johnston. London: Norton \& Company.

HOBSBAWM, Eric J. (1975). Bandidos. Traduzido por Donaldson Magalhães Garschagen. Rio de Janeiro: Editora Forense.

HOFF, Paul (1991). O pentateuco. Traduzido por Luiz Aparecido Caruso. Belo Horizonte: Editora Vida.

HOLSTI, Ole (2003). Crise é vital para futuro da ONU, diz analista. Entrevista. Em Folha de S. Paulo. Mundo. P. A12. 08/03/03. São Paulo: Empresa Folha da Manhã.

JELLINEK, Georg (1954). Teoría General del Estado. Traducido de la segunda edicion alemana y prólogo por Fernando de los Ríos. Editora Albatros: Buenos Aires.

JERUSALÉM, Escola Bíblica de (1985). Notas. Em A Bíblia de Jerusalém. Traduzidas por José Raimundo Vidigal, diretamente dos originais da Bíblia Hebraica de Stuttgart. P. 31-2329. São Paulo: Edições Paulinas.

JUSTIÇA, Ministério da (1996). Censo penitenciário de 1995. Departamento Penitenciário Nacional DEPEN. Conselho Nacional de Política Criminal e Penitenciária - CNPCP. Brasília: Imprensa Nacional.

KALTENMARK, Max (2000). Prefácio. En El taoismo y las religiones chinas. De Henri Maspero. P. 9-13. Madrid: Editorial Trotta.

KISSINGER, Henry (1996). Diplomacia. Traduzido por Ana Cecília Simões et alii. Lisboa: Gradiva.

LAO TZY (inédito). Tao. Reversão chinês-português por Luiz Sergio Modesto. Fonte nos manuscritos da $\mathrm{Fa}$ Chia (Escola Modelar) de Ma Wang Tui (-II), da Tao Chia (Escola Tao "Cósmico") de Wang Pi (+III), e da Tao Chiao (Escola "Mística") de Shang Hai Pan (+XX; Xilogravura de Shang Hai; explicação e comentário por Han Shan). São Paulo: Sibila Edicção.

LARA PEINADO, Federico (1994). Introducción y Notas. Em Enuma elish poema babilónico de la creación. Edición y traducción del acadio dialetal por Federico Lara Peinado. Colección Paradigmas. Biblioteca de Ciencias de las Religiones. P. 935; 91-113. Madrid: Editorial Trotta.

LAROUSSE (1995-6). China. Em Grande Enciclopédia Larousse Cultural. V. 6. P. 1361-1374. São Paulo: Nova Cultural.

LAROUSSE (1995-9). Estados Unidos da América (EUA). Em Grande Enciclopédia Larousse Cultural. V. 9. P. 2237-2248. São Paulo: Nova Cultural.

LAROUSSE (1995-24). Vietnã. Em Grande Enciclopédia Larousse Cultural. V. 24. P. 5945-5948. São Paulo: Nova Cultural. 
LÉCRIVAIN, Philippe (1991). Pour une plus grande gloire de dieu - les missions jésuites. Paris: Gallimard.

LINCOLN, The New Lincoln Library Encyclopedia. (1978). American History. In The Lincoln Library of essential information. V. 1. P. 439-516. Columbus. The Frontier Press Company.

MACKENZIE, John L. (1984). Dicionário biblico. Traduzido por Álvaro Cunha et alii. São Paulo: Edições Paulinas.

MARKERT, Christopher (1989). Yin-Yang - polaridade e harmonia em nossa vida. Traduzido por Alayde Mutzenbecher. São Paulo: Cultrix.

MASPERO, Henri (2000). El taoismo y las religiones chinas. Traducido por Pilar Gonzáles España y Rosa María López. Colección Paradigmas. № 25. Biblioteca de Ciencias de las Religiones. Madrid: Editorial Trotta.

MATEOS, Fernando; OTEGUI, Miguel; ARRIZABALAGA, Ignacio (1977). Diccionario español de la lengua china. Madrid: Espasa-Calpe.

MICROSOFT (1998). United States of America. In Microsoft Encarta Encyclopedia. U.S.A.: Microsoft Corporation.

MILES, Jack (1997). Deus: uma biografia. Traduzido por José Rubens Siqueira. São Paulo: Companhia das Letras.

MODESTO, Luiz Sergio (1994). As Drogas do Estado. Tese multidisciplinar fundamentada no paradigma metadisciplinar da Semioselogia apresentada perante a Faculdade de Direito da Universidade de São Paulo USP -, e defendida em 30/06/95, para obtenção do título de Doutor em Direito do Estado (Política). São Paulo: Sibila Edicção.

MODESTO, Luiz Sergio (1997-a). Regularidades políticas: mando-causal [ - ] e mando-casual [ - - ]. Em Revista da Faculdade de Direito Universidade de São Paulo. P. 243-254. V. 92, 1997, janeiro/dezembro. São Paulo: Universidade de São Paulo, Faculdade de Direito, Serviço Técnico de Imprensa.

MODESTO, Luiz Sergio (1997-b). ONU: fundamentalismo puritano no mercado. Em Drogas: a hegemonia do cinismo. Organizado por Maurides de Melo Ribeiro e Sérgio Dario Seibel. P. 91-104. São Paulo: Memorial - Fundação Memorial da América Latina.

MODESTO, Luiz Sergio (1998). "É preciso distinguir a relação entre você, seu prazer e o dano para terceiros, se houver". Em Se liga! O livro das Drogas. De Mylton (Myltainho) Severiano da Silva, Luiz Sergio Modesto, Davi Molinari. P. 190-216. Rio de Janeiro: Record.

MODESTO, Luiz Sergio (1999). Arquétrio Fratura Colateral da Cultura. Tese multidisciplinar fundamentada no paradigma metadisciplinar da Semioselogia apresentada perante o Programa de Estudos Pós-Graduados em Comunicação e Semiótica da Pontifícia Universidade Católica de São Paulo PUC-SP -, e defendida em 21/09/99, para obtenção do título de Doutor em Comunicação e Semiótica, em Curso de Pós-doutorado. São Paulo: Sibila Edicção. 
MODESTO, Luiz Sergio (200I). Paz de Lennon intimida coletividade-bando EUA. Em Caros Amigos. ISSN 1414-22 IX. № 55. Outubro de 2001. P. 25. São Paulo: Editora Casa Amarela.

MOISÉS (1985-1). Gênesis [B'reshit]. Em A Bíblia de Jerusalém. Traduzido por Domingos Zamagna, diretamente dos originais da Bíblia Hebraica de Stuttgart, com notas da École Biblique de Jérusalem. P. 31-105. São Paulo: Edições Paulinas.

MOISÉS (1985-2). Êxodo [Sh'mot]. Em A Bíblia de Jerusalém. Traduzido por Gilberto da Silva Gorgulho, diretamente dos originais da Bíblia Hebraica de Stuttgart, com notas da École Biblique de Jérusalem. P. 106-167. São Paulo: Edições Paulinas.

MONTAGU, Ashley (1988). Tocar, o significado humano da pele. Traduzido por Maria Sílvia Mourão Netto. São Paulo: Summus Editorial.

MOTYER, J. A. (1986). Os nomes de deus. Em O mundo da bíblia. Traduzido por José Raimundo Vidigal. P. 157-158. São Paulo: Edições Paulinas.

MÜLLER, Friedrich (1998). Quem é povo? A questão fundamental da democracia. Traduzido por Peter Naumann. Revisão de Paulo Bonavides. São Paulo: Max Limonad.

NATALI, João Batista (2003). Ativistas criam forma alternativa de política. Em Folha de S. Paulo. Mundo. P. A20. 16/03/03. São Paulo: Empresa Folha da Manhã.

NATIONS, People of the United (2002). Charter of the United Nations. 22/09/ 02. <http://www.un.org/aboutun/charter/index.html>.

PARKINSON, Dave; LAMOURIE, Tracy (2003). The telexecutioner - George W. Bush - President of The United States of America. 12/04/03. <http://www.ccadp.org/ serialpresident.htm>

PAULO, Folha de São (2001): Quem venceu?. Em Folha de S. Paulo. Opinião. Editoriais. P. A2. 20/11/01. São Paulo: Empresa Folha da Manhã.

PAULO, Folha de São (2002-a). Protestos marcam aniversário da intifada. Em Folha de S. Paulo. Mundo. P. A 18. 29/09/02. São Paulo: Empresa Folha da Manhã.

PAULO, Folha de São (2002-b). Saiba mais sobre a intifada. Em Folha de S. Paulo. Mundo. P. A I 8. 29/09/02. São Paulo: Empresa Folha da Manhã.

PAULO, Folha de São (2003-a). Recorde funesto. Em Folha de S. Paulo. Opinião. Editoriais. P. A2. 01/02/03. São Paulo: Empresa Folha da Manhã.

PAULO, Folha de São (2003-b). Bin Laden pede ataques suicidas, diz TV. Em Folha de S. Paulo. Mundo. P. A12. 12/02/03. São Paulo: Empresa Folha da Manhã.

PAULO, Folha de São (2003-c). Maior protesto da história pede paz. Em Folha de S. Paulo. Mundo. P. A15. 16/02/03. São Paulo: Empresa Folha da Manhã.

PAULO, Folha de São (2003-d). O mundo contra a guerra. Em Folha de S. Paulo. Mundo. P. A16-A 17. 16/02/03. São Paulo: Empresa Folha da Manhã.

PAULO, Folha de São (2003-e). Ação de Israel mata 11 palestinos e fere 140. Em Folha de S. Paulo. Mundo. P. A9. 07/03/03. São Paulo: Empresa Folha da Manhã. 
PAULO, Folha de São (2003-f). Israel mata 2 israelenses por engano e 5 palestinos. Em Folha de S. Paulo. Mundo. P. A12. 14/03/03. São Paulo: Empresa Folha da Manhã.

PAULO, Folha de São (2003-g). A América e o mundo. Em Folha de S. Paulo. Opinião. Editoriais. P. A2. 16/03/03. São Paulo: Empresa Folha da Manhã.

PAULO, Folha de São (2003-h). Entenda a crise. Em Folha de S. Paulo. Mundo. P. All. 19/03/03. São Paulo: Empresa Folha da Manhã.

PAULO, Folha de São (2003-i). Cidade já fez rebelião contra Saddam em 91. Em Folha de S. Paulo. Mundo. P. A15. 26/03/03. São Paulo: Empresa Folha da Manhã.

PAULO, Folha de São (2003-j). Os EUA e a guerra. Em Folha de S. Paulo. Mundo. P. A 16. 16/04/03. São Paulo: Empresa Folha da Manhã.

PAULO, Folha de São (2003-k). Helicóptero americano cai e mata 3. Em Folha de S. Paulo. Mundo. P. A16. 10/05/03. São Paulo: Empresa Folha da Manhã.

PEIRCE, Charles Sanders (1978-1). Principles of philosophy. In Collected papers of Charles Sanders Peirce. V. I. Cambridge: The Belknap Press of Harvard University Press.

PEIRCE, Charles Sanders (1978-2). Elements of logic. In Collected papers of Charles Sanders Peirce. V. II. Cambridge: The Belknap Press of Harvard University Press.

PETERS, F. E. (1983). Termos filosóficos gregos - um léxico histórico. Traduzido por Beatriz Rodrigues Barbosa. Lisboa: Fundação Calouste Gulbenkian.

PIAGET, Jean (1978). A formação do símbolo na criança imitação, jogo e sonho, imagem e representação. Traduzido por Álvaro Cabral e por Christiano Monteiro Oiticica. Rio de Janeiro: Guanabara, Koogan.

PINE, Red (PORTER, Bill) (1996). Introduction. Commentaries. Glossary. Em Taoteching. Lao-Tzu. Translated from chinese of the Mawangtui text, Fuyi text, Tunhuang text, and texts of Wang Hsi-chih, Yen Tsun, Ho-shang Kung, Wang Pi to english by Red Pine, with selected commentaries of the past 2000 years. P. IX-XXII; 2-163; 165-179. San Francisco: Mercury House.

PLATÃO (1990-21). Teeteto, o De la ciencia. Em Platón - obras completas. P. 892-941. Traduccion del griego, preambulo y notas por Jose Antonio Miguez. Madrid: Aguilar.

PLATÃO (1990-28). Las leyes, o De la legislación. Em Platón - obras completas. P. 1274-1516. Traduccion del griego, preambulo y notas Francisco de P. Samaranch. Madrid: Aguilar.

PRESS, Associated (2003). EUA ameaçam país que vetar nova resolução. Em Folha de S. Paulo. Mundo. P. A12. 13/03/03. São Paulo: Empresa Folha da Manhã.

REUTERS (2003). Empresa ligada a Cheney admite suborno na África. Em Folha de S. Paulo. Mundo. P. A 16. 10/05/03. São Paulo: Empresa Folha da Manhã. 
RIDLEY, Matt (2000). As origens da virtude um estudo biológico da solidariedade. São Paulo: Editora Record.

ROHTER, Larry (1994). EUA mantêm tradição centenária. The New York Times. Em Jornal da Tarde. Internacional. 17/09/94. P. I2. São Paulo: O Estado de São Paulo.

ROOS, Darius (2002). EUA usam videogame na guerra. Em Superinteressante. Supernovas. Edição 179. Agosto de 2002. P.22. São Paulo: Editora Abril.

SABINO, Mario (2003). A Europa estilhaçada. Em Veja. Especial. Edição 1796. P. 70-71. 02/04/2003. São Paulo: Editora Abril.

SAID, Edward (1997). Prefácio. Em História judaica, religião judaica - o peso de três mil anos. Traduzido por Artur Craveiro Lopes. P. 10-14. Lisboa: Hugin Editores.

SALGADO, Eduardo (2001). O império se desculpa. Em Veja. Internacional. Edição n² 1696. 18/04/02. P. 56-57. São Paulo: Editora Abril.

SANGER, David (2003). A doutrina de guerra de Bush. Do "The New York Times. Em Folha de S. Paulo. Mundo. P. A 16. 19/03/03. São Paulo: Empresa Folha da Manhã.

SANDOVAL, Pablo X. de (2003). Saldo de baixas entre civis pode chegar a 14 mil. Em Folha de S. Paulo. Mundo. P. A 19. 15/04/03. São Paulo: Empresa Folha da Manhã.

SHAHAK, Israel (1997). História judaica, religião judaica - o peso de três mil anos. Traduzido por Artur Craveiro Lopes. Lisboa: Hugin Editores.

TARDE, Jornal da (2002). Estes são os três homens mais perigosos do mundo. Em Jornal da Tarde. Mundo. P. 11 A. 03/09/02. São Paulo: O Estado de São Paulo.

TARDE, Jornal da (2003). De onde vêm as bombas que nos atingem. Em Jornal da Tarde. Editoriais. P. 3A. 20/03/03. São Paulo: O Estado de São Paulo.

TEICHER, Martin H. (2002). Scars that won't heal: the neurobiology of child abuse. In Scientific American. March 2002. V. 286. № 3. P. 54-61. New York: Scientific American.

TIMES, The New York (2002). Os números. Em O Estado de São Paulo. Panorama. 11/09/02. P. H2. São Paulo: O Estado de São Paulo.

VEJA (1994-1.361). O preço da glória. Em Veja. Notas internacionais. Edição 1.361. P. 93. 12/10/94. São Paulo: Editora Abril.

VEJA (1995-1.397). Os mercadores da morte. Em Veja. Notas internacionais. Edição 1.397. P. 45. 21/06/95. São Paulo: Editora Abril.

VEJA (2000-1.673). Essa é de doer. Em Veja. Educação. Edição 1.673. P. 94. 01/11/2000. São Paulo: Editora Abril.

VEJA (2002-1.747). Só a dor é a mesma. Em Veja. Edição 1.747. P. 46-49. 17 I 04/02. São Paulo: Editora Abril. 
VEJA (2002-1.751). Vítimas da guerra. Em Veja. Contexto. Edição 1.751. P. 33. 15/05/02. São Paulo: Editora Abril.

VULLIAMY, Ed (2003). Do fundo do copo ao topo do poder - a trajetória do homem que está prestes a lançar os Estados Unidos numa nova cruzada de conseqüências globais. The Observer. Em Carta Capital. Especial. Edição 227. P. 10-16. 12/02/03. São Paulo: Editora Confiança.

WEBER, Max (1980). Economía y sociedad, esbozo de sociología compreensiva. Traducido por José Medina Echavarría, Juan Roura Parella, Eugenio Ímaz, Eduardo García Máynez y José Fẹrrater Mora. México: Fondo de Cultura Económica.

WING-TSIT Chan (1973). A source book in chinese philosophy. Princeton (New Jersey): Princeton University Press.

WRANGHAM, Richard; PETERSON, Dale (1998). O macho demoniaco - as origens da agressividade humana. Traduzido por M. H. C. Côrtes. Rio de Janeiro: Editora Objetiva. 